\title{
1 Ammonoid and foraminiferal biostratigraphy from uppermost Valanginian to \\ 2 lowermost Barremian of the Jebel Boulahouajeb section (northern Tunisia)
}

3

4 Sarra Melliti a, Stéphane Reboulet b*, Nebiha Ben Haj Ali a, Mohammed Sabri Arfaoui c,

5 Fouad Zargouni a, Lucia Memmi $(\dagger)$

6

7 a Département de Géologie, Faculté des Sciences de Tunis, Université Tunis El Manar. El

8 Manar 2, 2092, Tunisie

9 b Université de Lyon, UCBL, ENSL, CNRS, LGL TPE, Bâtiment Géode, 2 rue Dubois, 1069622 Villeurbanne, France

11 c Deputy, exploration manager, PRIMOIL SA, Avenue de la Bourse, Immeuble Emeraude, $123^{\text {ème }}$ étage, Les Berges du Lac 2, Tunis, Tunisie

$13(\dagger)$ see acknowledgements

$14 *$ Corresponding author: stephane.reboulet@univ-lyon1.fr (S. Reboulet)

Abstract

17 A stratigraphic study was carried out on the Jebel Boulahouajeb section (Lansarine Chain; Tebourba area, northern Tunisia) in order to establish a relatively detailed biostratigraphic framework of the Hauterivian pelagic deposits of the Tunisian trough. The limestone-marl alternations are represented by five limestone-dominated intervals, named calcareous bundles

$21 \mathrm{H} 1$ to H5, separated by thick marly-dominated intervals. The well exposed Jebel

22 Boulahouajeb section (873 $\mathrm{m}$ in thickness) is relatively continuous, rich in ammonoid

23 macrofauna, and provides an ideal succession for this approach. Concerning the Hauterivian

24 ammonoid zonal scheme, the following (sub-)zones have been identified: Acanthodiscus

25 radiatus, Crioceratites loryi, Lyticoceras nodosoplicatum, Balearites balearis (with B. 
balearis, Balearites binelli, Balearites krenkeli and Balearites angulicostatus Subzones) and

Pseudothurmannia ohmi (with P. ohmi, Pseudothurmannia mortilleti and Pseudothurmannia picteti Subzones) Zones. Thus, except the Subsaynella sayni and Plesiospitidiscus ligatus

Zones, the standard zonation of the Mediterranean Province has been recognized in this area of the Tunisian trough. The boundaries of the Hauterivian stage have been characterized by identifying the last zone of Valanginian (Criosarasinella furcillata Zone) and the first zone of Barremian (Taveraidiscus hugii Zone). The benthic and planktic foraminiferal assemblages have been used to characterize some stratigraphic levels of the studied section; however the lack of certain data did not allow to well recognize and establish a complete zonal scheme. Mainly on the base of ammonoid biostratigraphy, the Jebel Boulahouajeb section is correlated with the Jebel Oust section (north-west of Zaghouan) that is the Lower Cretaceous reference section of the Tunisia trough.

Keywords: Ammonoids; Foraminifera; Hauterivian; Jebel Boulahouajeb; Jebel Oust; Tunisia

\section{Introduction}

In his monography on Mesozoic cephalopods of Tunisia, Pervinquière (1907) provided a subdivision of the Early Cretaceous series. This important work was completed by Solignac (1927) who focused his geological survey on the northern Tunisia. Since the middle part of the $20^{\text {th }}$ century, a succession of papers allowed to constraint the bio-lithostratigraphy of this interval using mainly ammonoids and foraminifera, and sometimes calpionellids (Castany, 1951; Bolze et al., 1952; Jauzein, 1967; Memmi, 1965, 1969, 1973, 1979, 1981, 1989; Busnardo and Memmi, 1972; Memmi and Maamouri, 1974; Stranik et al., 1974; Donze et al., 1975; Memmi and Salaj, 1975; Maamouri and Salaj, 1978; Salaj, 1980, 1984; Ben Haj Ali et al., 1993; Maamouri et al., 1994; Ben Haj Ali, 2005, 2006, 2008). Recently Ben Haj Ali and 
51 Memmi (2013) compiled a synthesis presenting a correlation between the ammonoid and

52 foraminifera zonal schemes for the Lower Cretaceous of northern Tunisia. Since Castany

53 (1951), the Jebel Oust locality (north-west of Zaghouan, $40 \mathrm{~km}$ South-East of Tebourba,

54 Tunisia trough) has been considered as a reference for the Lower Cretaceous marine

55 succession, and consequently numerous authors quoted previously focused on this section.

56 Due to its relative continuity and richness in micro and macrofauna, Salaj proposed, during

57 the meeting of the working Group on Pelagic Facies in Urbino in 1989, the Jebel Oust section

58 as a standard for marine Lower Cretaceous successions of the Tethyan realm (see Maamouri

59 et al., 1994). In his work on the Lansarine Chain (Tebourba area, northern Tunisia), Zargouni

60 (1975) described and figured two sections for the Lower Cretaceous series: the Jebel

61 Boulahouajeb and Tazega sections. The Jebel Boulahouajeb section appeared interesting for

62 the Valanginian-Aptian interval due to its important thickness and richness in ammonoids

63 that was also sampled by Solignac (1927). Zargouni (1975) underlined the presence in this

64 section of several foraminifera, calpionellid and nannofossil taxa. Considering the literature

65 on the stratigraphy of north Tunisia, it is important to note that, even in the works published

66 during the last decades, the stratigraphic columns of the most sections were generally not

67 detailed as they concerned the Lower Cretaceous period, and the sampling of macrofauna was

68 very sparse. The data was often presented as a species list, and the ammonoids collected were

69 generally not documented (rarely illustrated; as noted by Lehmann et al., 2009).

70 The aim of this work is to (1) establish a detailed biostratigraphic framework with both

71 ammonoids and foraminifera of the Jebel Boulahouajeb section, mainly for the Hauterivian

72 stage including the characterization of its boundaries, (2) illustrate some ammonoid and

73 foraminifera species of the studied section, and (3) establish correlations with the Jebel Oust

74 reference section using mainly the ammonoid data. The Jebel Boulahouajeb section provides

75 an ideal succession for this approach owing to the expanded, continuous well exposed 
outcrops and relatively abundant fossil records, in particular ammonoids which are relatively abundant and well preserved (see Melliti, 2012; Melliti et al., 2013).

\section{Geological setting}

The Jebel Boulahouajeb section is located in northern Tunisia near Tebourba city, about 40 km west of Tunis (Fig.1). The studied section belongs to the Lansarine Chain, delimited by the vast plain of the Medjerda valley to the south and east, and by the plain of the Oued Ettine to the north and north-west. The Mesozoic stratigraphy, palaeogeography, structures and tectonics of northern Tunisia were described by numerous authors as Burollet $(1956,1991)$, Bonnefous (1972), Zargouni (1975), Memmi et al. (1989), Bobier et al. (1991), Rais et al. (1991), Souquet et al., (1997), Chikhaoui et al. (1998), Soussi et al. (2000), Kamoun et al.

87 (2001), Bensalem (2002), Piqué et al. (2002), Soussi (2003), Boughdiri et al. (2006), Ben Abdesselam-Mahdaoui et al. (2010, 2011), Masrouhi et al. (2013), Naji et al. (2018a,b). The Jebel Boulahouajeb section belongs the Tunisian trough ("sillon tunisien”, Castany, 1951), a strongly subsiding basin from the Jurassic to Cretaceous time span. It corresponds to a deep marine palaeoenvironment characterized by pelagic-deep deposits. The Lower Cretaceous succession of this area is represented by very thick marly-limestone series with intercalation of some sandstone beds. Large and numerous diapiric intrusions of mainly evaporitic triassic material are also present (Perthuisot, 1981; Burollet, 1991). Zargouni (1975) described the Hauterivian-Aptian interval of the Jebel Boulahouajeb section, suggesting that this pelagic succession could start with the Valanginian; he noted the presence of a Triassic intrusion at its

97 base. In northeastern Tunisia, the Valanginian-Aptian succession is named the M'Chergua

98 Formation (Ben Ferjani et al., 1990; Burollet, 1991). Recently, it was raised to the rank of

99 Group and subdivided into four formations which are from the bottom up (Ben Haj Ali, 2008): El Mergueb (Valanginian to lower Hauterivian), Kef En Nemour (upper Hauterivian to 
101 upper Barremian), Sidi Amor (uppermost Barremian to basal Aptian) and Oued Ellouz

102 (Aptian) formations.

103

104

\section{Material and methods}

\subsection{Ammonoids}

106 A preliminary study of macrofauna of the Jebel Boulahouajeb section was started by Melliti 107 (2012) in the El Manar University of Tunis. This palaeontological material has been 108 completed by further samplings made by Melliti, from 2013 to 2016. Sampling of macrofaunal specimens was carried out at fifty four beds. Due to the thickness of the section

110 (873 m, see part 4.1), a bed by bed sampling was not possible for this preliminary study. The 111 marly intervals were not sampled as the outcrop conditions were not favourable. The selected

112 intervals were sampled for their content of pelagic (589 ammonoids representing 95\% of 113 macrofauna; 8 aptychi; 15 belemnites) and benthic macrofauna (1 bivalve and 6 echinoids);

114 nautiloids (shells and rhyncholites) were not found.

115 Dissolution of the ammonoid shells is the norm and specimens are preserved as internal 116 calcareous moulds. The ammonoid fauna is relatively well preserved, but the fragmentation of 117 specimens can be frequent in some beds. The compaction of specimens is relatively 118 important, particularly for the phragmocone. Consequently, some characteristics, such the 119 whorl section, the strength of ribs and tubercules, and how they change between the inner and 120 outer whorls, cannot be observed and compared for some specimens. The palaeontological 121 material was reviewed and taxonomically identified at the University of Lyon (Reboulet and 122 Melliti). The identification of ammonoids at specific level is sometimes difficult or 123 impossible. Some data are here presented at the generic level and some specimens identified 124 with doubt are indicated by a question mark. The material is stored in the palaeontological 
125 collections of the Observatory of Lyon at the Claude Bernard University of Lyon (France,

126 Melliti's collection).

\subsection{Foraminifera}

129 One hundred and fifty four samples were collected in the Jebel Boulahouajeb section; most of 130 them $(75 \%)$ come from the marly beds. Spacing is variable and ranges from less than $5 \mathrm{~m}$ to $13110 \mathrm{~m}$ as the section is very thick. In the laboratory, $300 \mathrm{gr}$ of each sample were analyzed at the 132 University of Tunis by Ben Haj Ali and Melliti. Marly sediments were soaked in tap water 133 and $\mathrm{H}_{2} \mathrm{O}_{2}$. After twenty four hours, the samples were washed through a set of sieves $(63 \mu \mathrm{m}-$ $134500 \mu \mathrm{m})$. The sieve with mesh opening of $63 \mu \mathrm{m}$ is recommended. Processed samples, once 135 dried, were stored in closed small plastic bags. The microfaunal assemblage is represented by 136 benthic and planktic foraminifera, ostracods (rare) and echinoid spines (frequent). It is 137 necessary to note that planktic foraminifera were carried out only in the fine fraction. They 138 have a well preserved calcitic test, unlike for the forms described in other sections of the 139 northeastern Tunisia, which are represented by a pyritised test. Due to their very small size, 140 their identification is often difficult. Even if planktic foraminifera are rare, they have been 141 studied for their biostratigraphic interest. The benthic foraminifera are common to frequent in 142 residus and were found in the coarse and fine fraction. Despite of their abundance, just a 143 preliminary study of this group is presented here. The samples were examined under a 144 binocular microscope with optics power twenty times; this magnification is not very adequate 145 to recover easily very small planktic foraminifera. Specimens were mounted in one hundred 146 and sixty cell-slides. Representative specimens illustrated were photographed using Scanning

147 Electron Microscope. The selection of illustrated specimens is based on the stratigraphic 148 importance of the index-species of planktic foraminifera and the importance of associated 149 benthic foraminifera taxa. 


\section{Results}

152

153

154

155

156

157

158

159

160

161

162

163

164

165

166

167

168

169

170

171

172

173

174

\subsection{Description of the Jebel Boulahouajeb section}

The Jebel Boulahouajeb section (JBH; $873 \mathrm{~m}$ in thickness) is composed by two complementary sections (sections JBH-A and JBH-B) from the M'Chergua Group (sensu Ben Haj Ali, 2008), with abnormal contact of Triassic deposits at the base. On the well-exposed intervals, all beds have been identified and drawn on the field notebook (Melliti, Ben Haj Ali and Sabri Arfaoui); however, due to the important thickness of the section JBH-B, the drawn scheme was simplified. Outcrop conditions are sometime less favorable to make a precise observation as some marly-dominated intervals are more or less affected by scree-cover. The section JBH-A (Fig. 2; 50 m. thick) starts with a metric bed of red sandstone, followed by an alternation of yellowish limestones and gray marls, attributed to the upper Valanginian. The section JBH-B (Fig. 3ab; $823 \mathrm{~m}$ thick) starts after a lateral displacement of $10 \mathrm{~m}$ to north-west from the top of section JBH-A. About $20 \mathrm{~m}$ of limestone-marl alternations of the upper Valanginian are exposed at the base of the succession. The Hauterivian is represented by $783 \mathrm{~m}$ of thickness, including a $65 \mathrm{~m}$ gap of observation. The deposits are made of nodulous limestones, yellow in patina and grey colour when broken, and alternating grey marls. The succession is characterized by calcareous bundles that are limestone-dominated intervals (thick calcareous beds and reduction of marl-bed thickness); they are separated by thick marl-dominated intervals. Starting by a sandstone bed (JBH-B3; 3 m, ochre's color), the lower part of the section JBH-B is composed by two calcareous bundles named H1 (JBH-B5 to $\mathrm{B} 20 ; 34 \mathrm{~m}$ ) and $\mathrm{H} 2$ (JBH-B22 to B32; $27 \mathrm{~m}$ ), separated by a marly interval. In the middle part of the section JBH-B, the marly interval is characterized by two calcareous bundles, named H3 (JBH-B86 to B97; $24 \mathrm{~m}$ ) and H4 (JBH-B163 to B170; $28 \mathrm{~m}$ ), and several more or less continuous sandstones or siltstones beds (above JBH-B32, JBH-B48-59-65-72-75, above 
175 JBH-B115, and JBH-B181). In the upper part of the section JBH-B, a succession of thick beds

176 allows to recognize a fifth calcareous interval named H5 (JBH-B202 to B219; 26 m), knows

177 as the "cornice of Jebel Boulahouajeb" of Zargouni (1975). The uppermost part of the section

$178 \mathrm{JBH}-\mathrm{B}$ is represented by marls and grey limestones attributed to lowermost Barremian (20 m).

179

180 4.2. Ammonoids

$181 \quad 4.2 .1$. Systematics

182 The ammonoid fauna of the studied section consists of thirty one genera grouped into fourteen 183 families and nine super-families (Appendix 1), mainly using the classification proposed by 184 Klein (2005), Vermeulen and Klein (2006), Klein et al. (2007, 2009), and Klein and Vašíček 185 (2011). As the purpose is not to make a systematic revision, only palaeontological comments 186 are made for some taxa and quantitative data are also given. Further information is available 187 in the papers of Company (1987), Reboulet et al. (1992), Bulot et al. (1993), Bulot (1995), 188 Hoedemaeker (1995, 2013), Reboulet (1996), Cecca et al. (1998), Reboulet and Atrops 189 (1999), Busnardo et al. (2003), Company et al. (2003, 2005), Vermeulen (2003), Ettachfini 190 (2004), Vermeulen et al. (2012, 2013).

191

192 Neocomitids are rare to common and they occur in the lower part of the Jebel Boulahouajeb 193 section (section JBH-A, Fig. 2; section JBH-B, Fig. 3a). They are represented by Teschenites 194 (12 specimens), Eleniceras (3 specimens), Lyticoceras (4 specimens; Figs. 4A and 4B), 195 Jeanthieuloyites (6 specimens) and Spitidiscus (31 specimens). Due to the relatively bad 196 preservation of the material in these beds, the identification of species is difficult for the first 197 three genera; only few Teschenites subflucticulus (Fig. 4C) have been recognized in beds 198 JBH-A5 and A7. In this interval also occur Jeanthieuloyites keyserlingiformis (Fig. 4D), 199 Jeanthieuloyites quinquestriatus (Fig. 4E) and Jeanthieuloyites solignaci (Figs. 4F and 4G). 
The first Spitidiscus (identified with doubt) occurs in JBH-B7; the lowest occurrences (LO) of

201 Spitidiscus lorioli (Figs. 4H and 4I) and Spitidiscus meneghini (Figs. 4J, 4K, 4L) are recorded

202 in beds JBH-B9 and B10, respectively; only one Spitidiscus rawsoni (Fig. 4M) have been

203 found in bed JBH-B30. Even though Himantoceras is characterized by a crioconic shell, this

204 genus should be assigned to the Neocomitinae (the phyletic relation has been shown by

205 Reboulet, 1996, 2007, 2008) and not to the Ancyloceratids as kept by Klein et al. (2007). One

206 specimen of Himantoceras cf. trinodosum (Fig. 4N) has been found in bed JBH-B4.

207 Olcostephanids are common to frequent in some beds. Among Olcostephanus (62 specimens),

208 Olcostephanus densicostatus (Figs. 5A and 5B) has been identified in the section JBH-A (Fig.

209 2). Jeannoticeras jeannoti (2 specimens; Fig. 5C) has been recorded in beds JBH-B20 and

210 B21 (Fig. 3a).

211 Oosterellids are rare and this family is represented by three species of Oosterella (8

212 specimens; Figs 2 and 3a): Oosterella ondulata (Fig. 5D), Oosterella cultrata (Fig. 5E) and

213 Oosterella cultrataeformis.

214 Holcodiscids are very rare and only three specimens of Avramidiscus intermedius (Fig. 6A)

215 have been found at the uppermost part of the section JBH-B (beds JBH-B232 and B234; Fig.

$2163 b)$.

217 Barremitids are mainly represented by Plesiospitidiscus (50 specimens): Plesiospitidiscus

218 fasciger (Figs. 6B and 6C) have been sampled in beds JBH-B18 and B20 (Fig. 3a); the middle

219 part of the section JBH-B is characterized by Plesiospitidiscus subdifficilis (Figs. 6D and 6E;

220 Fig. 3b). In this interval, one Abrytusites neumayri (Fig. 6F) has been recorded. Other genera

221 of this family occur in the upper part of the section JBH-B with one Barremites gr. cassida

222 (Fig. 6G), two Montanesiceras cf. dimboviciorensis and two Valdedorsella? uhligi (Fig. 6H).

223 Pulchelliids are very rare in the section JBH-B and only five specimens of Discoidellia have

224 been recorded (Fig. 3b): Discoidellia cf. couratieri (Figs. 6I and 6J) and Discoidellia favrei. 
225 Haploceratids, with Neolissoceras grasianum (Fig. 7A), mainly occurs in the section JBH-A

226 and in the lowermost part of the section JBH-B (13 specimens; Figs. 2 and 3a); only one

227 specimen has been sampled in the middle part of the section JBH-B (bed JBH-B163; Fig. 3b).

228 Phylloceratoids are represented by Phylloceras (Hypophylloceras) with 16 specimens

229 (Phylloceras (Hypophylloceras) tethys, Fig. 7B; Phylloceras (Hypophylloceras) ponticuli)

230 and Phyllopachyceras with 31 specimens (Phyllopachyceras winkleri, Fig. 7C;

231 Phyllopachyceras infundibulum, Figs. 7D and 7E) which are more frequent in the lower part

232 rather in the upper part of the section JBH-B (Figs.2 and 3ab). This last species has not been

233 found in the section JBH-A (Fig. 2); it seems that the first specimen (identified with doubt)

234 occurs in bed JBH-B9 (Fig. 3a).

235 Lytoceratids (61 specimens) are represented by Lytoceras subfimbriatum (Figs. 7F and 7G);

236 the genus Lytoceras is relatively common (Figs. 2 and 3ab).

237 Crioceratitids are represented by Balearites (69 specimens) and Pseudothurmmania (161

238 specimens) which are relatively abundant, particularly in beds JBH-B163 and B202,

239 respectively (Fig. 3b). In this work, the opinion of Company et al. (2003) is followed:

240 Balearites balearis, Balearites binelli, Balearites krenkeli and Balearites angulicostatus could

241 constitute a phylogenetic lineage. These species were included in the genus Criocertaties by

242 these authors. More recently, the first three species were considered as belonging to

243 Balearites by Vermeulen et al. (2012). However, these both teams have a different conception

244 of the genus Balearites; for Vermeulen et al. (2012), some species of Pseudothurmannia

245 should be included in Balearites, and these authors do not consider angulicostatus as a

246 Balearites. Taking into account their new data and observations, Matamales and Company

247 (personnal communication, 2017) suggest that the group/lineage balearis-binelli-krenkeli-

248 angulicostatus should belong to the genus Balearites. According to Company et al. (2003),

249 the evolutionary trend of this group is towards "a stronger ornamentation and a clear 
differenciation between main and intermediate ribs in the middle ontogenetic stages". The

251 ornamentation of $B$. balearis is characterized in the middle stages by uniform and dense ribs

252 lacking distinct umbilical tubercules. In bed JBH-B92 (Fig. 3b), three specimens have been

253 identified as B. cf. balearis (Fig. 8A). The second member of the lineage is B. binelli (Figs.

$2548 \mathrm{~B}$ to $8 \mathrm{E}$ ); it differs in the appearance of ribs bundles rising from well-defined umbilical

255 bullae. B. binelli seems relatively frequent as fifteen specimens have been sampled in bed

$256 \mathrm{JBH}-\mathrm{B} 163$ and numerous Balearites sp. ind. found in this bed probably belong to this species.

257 The next species of the group is B. krenkeli; a clear differentiation between main and

258 intermediate ribs from quite early ontogenetic stage can be observed. One specimen belonging

259 to bed JBH-B195 is identified with doubt to this species (Fig. 8F). Balearites angulicostatus

260 is the last species of this lineage and the ancestor of Pseudothurmannia forms (Hoedemaeker,

261 1995; Company et al., 2003). In the studied section, two specimens are identified as

262 Balearites cf. angulicostatus (Figs. 8G and 8H) in bed JBH-B195. In their work, Company et

263 al. (2003) recognized four species of Pseudothurmannia. These authors observed the

264 consecutive appearance of Pseudothurmannia ohmi, Pseudothurmannia mortilleti and

265 Pseudothurmannia picteti; this evolutionary trend is towards a more involute coiling. They

266 noted that $P$. ohmi "differs from its ancestor anguliscostatus in having the whorls always in

267 touch and having definitively lost the initial trituberculate stage”. In the Jebel Boulahouajeb

268 section, P. mortilleti (Figs. 9A to 9E) is well represented and co-occurs with

269 Pseudothurmannia pseudomalbosi (Figs. 9F, 9G and 10A). Just above this stratigraphic

270 interval, one specimen of $P$. picteti (Fig. 10B) has been recorded (bed JBH-B219, Fig. 3b). $P$.

271 ohmi has not been recognized. Taking into account the stratigraphic distribution of the last

272 Balearites and first $P$. mortilleti found in beds JBH-B195 and JBH-B202, respectively, $P$.

273 ohmi should take place in this interval (from top JBH-B195 to base JBH-B202) in which first

274 specimens of Pseudothurmannia sp. ind. have been sampled (bed JBH-B200); indeed, 
275 according to the distribution of species given by Company et al. (2003), Balearites (balearis-

276 binelli-krenkeli-angulicostatus group) and Pseudothurmannia (ohmi-mortilleti-picteti group)

277 do not coexist (no overlapping of their ranges). The identification at the specific level was not

278 possible for the three specimens of Sornayites found in this part of the section JBH-B

279 characterized by numerous Pseudothurmannia.

280 Emericiceratids (2 specimens: Honnoratia cf. thiollieri; Paraspiticeras sp. ind., Fig. 10C),

281 Leptoceratoidids (4 specimens: Hamulinites sp. ind.; Sabaudiella simplex, Fig. 10D) and

282 Hamulinids (2 specimens: Anahamulina lorioli; Amorina?) are very rare and restricted in the

283 upper part of the section JBH-B (Fig. 3b). Bochianitids (5 specimens: Bochianites

284 neocomiensis) have been found in the section JBH-A and in the lowermost part of the section 285 JBH-B (Figs. 2 and 3a).

286

287 4.2.2. Biostratigraphic implications

288 According to the stratigraphic distributions of ammonoid taxa of the studied section (Figs. 2

289 and 3ab), the whole Hauterivian stage is represented in the Jebel Boulahouajeb section. Most

290 of the Hauterivian zones of the Standard zonation (Hoedemaeker et al., 2003; Reboulet et al.,

291 2018) have been recognized. All of these are interval zones and their lower boundary is

292 identified by the LO of the index-species (their upper boundary is identified by the base of the

293 next zone). The main references concerning the stratigraphic distribution of taxa allowing to

294 characterize the zones are indicated.

295 The section JBH-A belongs to the Criosarasinella furcillata Zone (Fig. 2), of Valanginian

296 age, taking into account the occurrence of Teschenites sp. ind., T. subflucticulus (Reboulet,

297 1996; Reboulet and Atrops, 1999) and J. keyserlingiformis (Avram, 1995). This interval is

298 also marked by the occurrence of Eleniceras sp. ind., O. densicostatus, O. ondulata, J.

299 quinquestriatus and J. solignaci; these taxa are present in the uppermost part of the 
300 Valanginian, but they are also known in the lowermost part of the Hauterivian (Reboulet, 301 1996). The Hauterivian is not characterized here due to the absence of Spitidiscus and P. 302 unfundibulum.

303 The Valanginian-Hauterivian boundary can be drawn in the lowermost part of the section 304 JBH-B (Fig. 3a), and is placed at the base of bed JBH-B7 in which a specimen of Spitidiscus 305 sp. ind. has been found. When Acanthodiscus or Breistrofferella are absent (Acanthodiscus 306 radiatus is the index-species of the first zone of the Hautervian stage), the LO of Spitidiscus 307 can be used to characterize the base of the Hauterivian (Reboulet, 1996; Busnardo et al., 308 2003). Just below bed JBH-B7, a specimen of $H$. cf. trinodosum has been recorded in bed 309 JBH-B4. According to Reboulet (1996; see also Reboulet and Atrops, 1999), H. trinodosum is 310 restricted to the upper Valanginian. Bulot et al. (1993) found in the lowermost part of the $A$. 311 radiatus Zone (La Charce section, France) a (or few?) specimen(s) of Himantoceras identified 312 as $H$. cf. trinodosum. This/these specimen(s) could correspond to Himantoceras n. sp. 2, taxa 313 described by Reboulet (1996) and located in the basal part of the A. radiatus Zone (only three 314 specimens found in the Les Sias section, France). Consequently, H. trinodosum should be 315 restricted to the upper Valanginian. The A. radiatus Zone is characterized by the occurrences 316 of S. lorioli, S. meneghini and P. infundibulum (Bulot, 1995; Reboulet, 1996); all or a part of 317 these taxa are recorded in beds JBH-B9 and B10. The assemblage of the interval JBH-B8 to 318 B10 is also characterized by Teschenites sp. ind., O. cultrata and O. cultrataeformis. The bed 319 JBH-B9 could correspond to the middle part of the A. radiatus Zone as the range of these 320 Oosterrelid species ends in the lower part of this zone in SE France and the range of $P$. 321 unfundibulum starts in its upper part (Reboulet, 1996).

322 The Crioceratites loryi Zone is not directly characterized as the index-species has not been 323 found. In the Jebel Boulahouajeb section, the highest occurrence (HO) of S. meneghini and S. 324 lorioli (in bed JBH-B11) is used to put the lower boundary of this zone at the base of bed 
JBH-B12 (Fig. 3a). Even if Reboulet (1996) noted the occurrence of S. meneghini in the

326 lowermost part of the C. loryi Zone, it seems that these both species of Spitidiscus are mainly 327 restricted in the A. radiatus Zone (see Bulot, 1995).

328 The Lyticoceras nodosoplicatum Zone has been recognized with the LO of Lyticoceras sp. 329 ind. in bed JBH-B20 (Fig. 3a). The fact that this taxa co-occurs with $P$. fasciger, in bed JBH$330 \mathrm{~B} 20$, and J. jeannoti, in beds JBH-B20 and 21, allows to characterize the lowermost part of 331 the zone (the Olcostephanus variegatus Horizon; Bulot, 1995). Lyticoceras sp. ind. and S. 332 rawsoni have been found in beds JBH-B24 and B30, respectively; according to Bulot (1995) 333 and Reboulet (1996) these both taxa are restricted to the L. nodosoplicatum Zone.

334 The Subsaynella sayni and Plesiospitidiscus ligatus Zones have not been identified as the 335 interval from the top of JBH-B30 to the base of JBH-B86 has not been sampled for 336 macrofauna (Fig. 3a). Consequently, the upper boundary of the L. nodosoplicatum Zone is 337 provisionnaly placed at the top of bed JBH-B30.

338 The Balearites balearis Zone is well identified in the studied section. Its base is placed at the 339 base of bed JBH-B92 in which several specimens of Balearites sp. ind. and B. cf. balearis 340 have been recorded (Fig. 3b). Two specimens identified with doubt to the genus Balearites 341 have been found in beds JBH-B86 and B89. This interval is also characterized by the 342 occurrence of $P$. subdifficilis and D. cf. couratieri; according to Company et al. (2003), the 343 LO of these two latter species are at the base of the B. balearis Zone. These observations 344 could be in favour to place the base of this zone at bed JBH-B86. However, even if the acme 345 of D. couratieri occurs in the B. balearis Zone (Vermeulen, 1995), the LO of D. couratieri is 346 in the lower part of the P. ligatus Zone (Vermeulen, 2003). Due to the difficulty in identifying 347 the different species of Plesiospitidiscus and considering that their stratigraphic distribution is 348 not well known around the interval of the P. ligatus Zone, it is preferable not to put the base 349 of the B. balearis Zone at the LO of P. subdifficilis. The lower boundary of Balearites binelli 
350 Subzone is placed at the base of bed JBH-B163 where its index-species occurs. It is difficult

351 to identify the upper boundary of this subzone. The lower boundary of Balearites

352 angulicostatus Subzone is drawn at the LO of B. cf. anguliscostatus sampled in bed JBH-

353 B195. In this bed, there is also B. krenkeli?; the specimen probably represents the end of the

354 range of the species. Indeed, according to Company et al. (2003), B. anguliscostatus and B.

355 krenkeli co-exist in a short stratigraphic interval of the lowermost part of the B. angulicostatus

356 Subzone. Thus, the $B$. krenkeli Subzone can be provisionaly assigned to the interval from the

357 top of bed JBH-B170 (just above the range of B. binelli) to the base of bed JBH-B195 (just

358 below the LO of $B$. cf. angulicostatus).

359 The Pseudothurmannia ohmi Zone is well characterized. Its lower boundary is placed at the

360 base of bed JBH-B200 where one specimen of Pseudothurmannia sp. ind. has been recorded

361 (Fig. 3b). As observed by Company et al. (2003) for the SE Spain, the HO of $L$.

362 subfimbriatum and P. subdifficilis are recorded in the lower part of the zone of the Jebel

363 Boulahouajeb section; a comparison with their work can also be done for $V$.? cf. uhligi, M. cf.

364 dimboviciorense and D. favrei that are sampled in the P. ohmi Zone of the studied section.

365 The base of the Pseudothurmannia mortilleti Subzone is placed at the base of bed JBH-B202

366 where its index-species first occurs. Its range is similar to that of P. pseudomalbosi; this is in

367 accordance with the data of Company et al. (2003). The lower boundary of $P$. picteti Subzone

368 is put at the base of bed JBH-B219. This subzone is difficult to characterize as there is a large

369 stratigraphic interval (65 $\mathrm{m}$ in thickness) without observation.

370 The Hauterivian-Barremian boundary is provisionaly placed at the base of bed JBH-B232

371 where the LO of $A$. intermedius is recorded (Fig. 3b), even if this species first occurs in the

372 uppermost part of the P. picteti Subzone as observed by Company et al. (2003). The base of

373 the Barremian stage is also characterized by the presence of $B$. gr. cassida found in bed JBH-

374 B234. 


\subsection{Foraminifera}

\subsubsection{Systematics}

378 The micropaleontological study of planktic foraminifera is based essentially on the work of 379 Moullade (1974), Caron (1985), Premoli-Silva and Sliter (2002), Ben Haj Ali (2005; 2006), 380 Ben Haj Ali and Memmi (2013; Appendix 2). Their determination is often difficult due to the 381 very small size of the studied specimens; the problem of the identification of the lowermost 382 Cretaceous planktic foraminifera was also noted by Cecca et al. (1994) and Coccioni and 383 Premoli-Silva (1994). As also underlined by these authors for this interval in Italy and Spain 384 respectively, the planktic foraminiferal assemblages of the Boulahouajeb section is poorly 385 diversified; this was also observed in north-west Tunisia by Ben Haj Ali (2005) and Ben Haj 386 Ali and Memmi (2013). In the studied section (Fig. 11), Favusellids are represented by 387 Favusella hoterivica (Figs. 12A and 12B). Praehedbergellids are composed by two genera: Gorbachikella, represented by Gorbachikella kugleri (Figs. 12C and 12D), Gorbachikella anteroapertura (Fig. 12E) and Gorbachikella grandiapertura, and Praehedbergella

390 represented by Praehedbergella sigali (Figs. 12F to 12H). Planktic foraminifera occur only in 391 the upper part of the section (Fig 11). They are rare to very rare but $P$. sigali is more abundant 392 in the upper part of its range. The low abundance of the small planktic forms in the 393 Valanginian and Hauterivian stages is also noted by Coccioni and Premoli-Silva (1994).

394 Benthic foraminifera are represented by thirty six taxa, which constitute the main part of the 395 assemblages (Fig. 11). Their palaeontological study is based on Moullade (1974), Neagu 396 (1975), and Holbourn and Kaminski (1995). In the studied section, calcareous taxa are 397 represented by nine genera (Lenticulina, Dentalina, Frondicularia, Marginulinopsis, 398 Catharina, Ramulina, Marginulina, Spirillina and Gavelinella) including twenty two 399 species/taxa. The agglutinated foraminifera, that are generally less frequent, are composed by 
five genera (Dorothia, Marsonella, Ammodiscidus, Bathysiphon and Rhizimina) including

401 fourteen species/taxa. A poor assemblage of benthic foraminifera is recorded in the upper

402 Valanginian interval (6 samples; from JBH-B1 to B6) that is characterized by the occurrence

403 of rare Lenticulina roemeri (Fig. 12I). A moderate diversification is observed in the lower

404 Hauterivian of the Jebel Boulahouajeb section. A stronger increase of number of taxa is

405 recorded from the lowermost part of the upper Hauterivian (from level JBH-B76 to the top of

406 the section). The foraminiferal succession for the studied Hauterivian section is subdivided

407 into nine assemblages based on changes in the composition of dominant taxa and on

408 occurrences of species with biochronological interest: Lenticulina eichenbergi (Fig. 12J),

409 Dorothia lilliformis (Fig. 12K), Lenticulina multicella (Fig. 12L), Dorothia praehauteriviana

410 (Fig. 12M), Lenticulina ouachensis ouachensis (Fig. 12N), Dorothia kummi (Fig. 12O),

411 Dorothia zedlerae (Fig. 12P), Lenticulina rotulata (Fig. 12Q) and Gavellinella barremiana

412 (Fig. 12R). These index-species are accompanied by other abundant benthic species (Fig. 11).

413

\section{4.3.2. Biostratigraphic implications}

415 The planktic foraminifera zonation adopted in this work (Fig. 11) corresponds to the local

416 zonal scheme established by Ben Haj Ali (2005) and Ben Haj Ali and Memmi (2013).

417 Contrary to Maamouri et al. (1994), benthic foraminifera are not used here to define

418 foraminiferal subzones because the occurrence and distribution of the group is highly

419 controlled by local ecological conditions (see Moullade, 1974).

420 No planktic forms have been observed in the uppermost Valanginian-lower Hauterivian of

421 the Jebel Boulahouajeb section. This could be partly explained by the difficulty to identify

422 specimens due to their small size. Salaj (1984) and Ben Haj Ali (2005; see also Ben Haj Ali

423 and Memmi, 2013) have noted that the LO of planktic foraminifera are respectively at the

424 base of the lower Hauterivian and the base of the upper Hauterivian. The low diversification 
425 of the lowermost Cretaceous foraminiferal planktic assemblages and their scarceness

426 (Coccioni and Premoli-Silva, 1994; Cecca et al 1994; Robaszynski and Caron, 1995) could

427 also explain why these microfossils have not been found in this interval of the studied section.

428 In the Jebel Boulahouajeb section, only five planktic foraminifera species have been recorded

429 in the upper Hauterivian-lowermost Barremian interval. The first bioevent (JBH-B37 at the

430 lowermost part of the upper Hauterivian) is characterized by the LO of Favusella hoterivica.

431 The F. hoterivica Interval Range Zone is identified by the LO of the index-species (Van

432 Hinte, 1972). In the Cretaceous Mediterranean zonal scheme based on planktic forminifera,

433 Sigal (1977) indicated that "Caucasella gr. hauterivica-kugleri" first occurs at the base of the

434 upper Hauterivian (see also Caron, 1985). In Tunisia (Jebel Oust area), F. hoterivica first

435 occurs at the base of the Hauterivian (Salaj, 1984). For Maamouri et al. (1994), the

436 "Globuligerina hoterivica Zone" characterizes the Hauterivian stage. According to Coccioni

437 and Premoli-Silva (1994), the "mean range" of " $C$. hauterivica" starts at the base of the

438 Hauterivian (synthetic data); however these authors indicated that the LO of this species in SE

439 Spain is at the base of "Thurmanniceras" pertransiens Zone (base of the Valanginian).

440 According to Ascoli (1988 in Robaszynski and Caron, 1995), the LO of F. hoterivica could be

441 lower, in the middle-late Berriasian in the NW Atlantic margin of North America. In the Jebel

442 Boulahouajeb section, only a short part of the stratigraphic range of $F$. hoterivica is recorded

443 corresponding to the lower part of the upper Hauterivian. Consequently, it is not really

444 possible to identify this zone in the studied section.

445 The second set of bioevents concerns the LO of three species belonging to Gorbachikella: $G$.

446 kugleri, G. anteroapertura and G. grandiapertura in levels JBH-B73, B91, B109,

447 respectively. As previously evoked, the range of "Caucasella gr. hauterivica-kugleri" would

448 start at the base of the upper Hauterivian (Sigal, 1977). In north Tunisia, BouDagher-Fadel et

449 al. (1995) indicated that G. kugleri occurs in the Hauterivian and its range goes up to the 
450 lower Aptian. Ben Haj Ali (2005) recorded the LO of G. kugleri at the base of the upper

451 Hauterivian and she defined the G. kugleri Interval Zone that characterized this substage (see 452 also Ben Haj Ali and Memmi, 2013). When BouDagher-Fadel et al. (1995) described the new 453 species G. grandiapertura and G. anteroapertura they did not provide their stratigraphic 454 distribution; the authors indicated that G. grandiapertura ranges in Tunisia from Hauterivian 455 to Barremian, and G. anteroapertura ranges from the upper Hauterivian to lower Aptian. For 456 Ben Haj Ali (2005), these two species allow to characterize the G. kugleri Zone. Refering to 457 the zonal scheme of this author, the LO of G. kugleri in the Jebel Boulahouajeb section is 458 used to indicate the base of the G. kugleri Zone that is also characterized by $G$.

459 grandiapertura and G. anteroapertura (Fig. 11).

460 The third bioevent in the planktic distribution of the Jebel Boulahouajeb section is the LO of 461 Praehedbergella sigali in level JBH-B221. For Sigal (1977), "Hedbergella sigali” first occurs 462 at the base of the Barremian (see also Caron, 1985). It is the index-species of the first planktic 463 foraminifera zone of this stage; this interval zone was defined by Moullade (1966). For 464 Maamouri et al. (1994), H. sigali should be put in synonymy with Hedbergella tuschpsensis; 465 its LO is recorded at the base of the Barremian and this defined the base of the $H$.

466 tuschpsensis Interval Zone. According to Coccioni and Premoli-Silva (1994), the "mean 467 range" of " $H$. sigali" starts at the base of the Barremian (synthetic data); however, these 468 authors indicated that this species first occurs at the base of "T." pertransiens Zone in SE 469 Spain. Robaszynski and Caron (1995) underlined that H. sigali is rare in the Valanginian and 470 becomes more frequent during the Hauterivian and Barremian. More recently, Premoli-Silva 471 et al. (2017) confirmed that H. sigali is already present in the upper Hauterivian of SE Spain.

472 Ben Haj Ali (2005) was the first to recognize the $P$. sigali Zone as the first zone of the 473 Barremian in Tunisia (see also Ben Haj Ali and Memmi, 2013). In the Jebel Boulahouajeb 
474 section, a similar observation is done; the base of the P. sigali Zone is placed in the uppermost

475 part of the Hauterivian where the LO of its index-species is recorded.

\section{5. Discussion}

\section{5.1. Integrated biostratigraphy: ammonoid and foraminifera zonations}

479 The callibration of the ammonoid and planktic foraminifera zonations proposed here is

480 restricted to the upper Hauterivian-lowermost Barremian of the Jebel Boulahouajeb section

481 (Figs. 3 and 11). The LO of G. kugleri and G. anteroapertura are in the upper part of the $S$.

sayni-P. ligatus Zones. G. grandiapertura first occurs in the lowermost part of the $B$. balearis

483 (Sub-)Zone. These three foraminifera species also occur in the P. ohmi Zone. So, they

484 characterize the upper Hauterivian as observed in other Tunisian sections by BouDagher-

485 Fadel et al. (1995), Ben Haj Ali (2005), and Ben Haj Ali and Memmi (2013). Taking into

486 account the ammonoid distributions of the Jebel Boulahouajeb section, the base of the

487 Barremian is placed at bed JBH-B232 (LO of A. intermedius), and so the LO of $P$. sigali

488 (JBH-B221) is recorded in the upper part of the P. ohmi Zone (P. picteti Subzone). However,

489 the Hauterivian-Barremian boundary could be lowered at level JBH-B221 where the LO of $P$.

490 sigali is recorded. Indeed, as the ammonoid Taveraidiscus hugii (index-species of the first

491 Barremian zone) has not been found, this boundary can be placed between the HO of

492 Pseudothurmannia (in bed JBH-B219; this genus is restricted in the uppermost part of the

493 Hauterivian; Busnardo et al., 2003; Company et al., 2003; Hoedemaeker, 2013) and the LO of

494 A. intermedius (bed JBH-B232). In this interval, ammonoid species with a biostratigraphic

495 interest as D. favrei and B. cf. dimboviciorensis are rare and they can occur in the P. ohmi and

496 T. hugii Zones. The proposal to put the base of the Barremian stage at level JBH-B221 could

497 be supported considering that $P$. sigali is the index-species of the first Barremian zone in

498 Tunisia. However, as previously evoked, the LO of $P$. sigali is placed lower in other areas of 
the Tethyan realm (base of the Valanginian in Spain). Consequently, the Hauterivian-

500 Barremian boundary is kept at the base of bed JBH-B232.

\subsection{Correlations: Jebel Boulahouajeb and Jebel Oust sections}

503 The Jebel Boulahouajeb section is correlated with the Jebel Oust section (Fig. 13) that is

504 considered as the reference section for the northern Tunisian lower Cretaceous series (see

505 Introduction chapter). This correlation is made using the biostratigraphic data (ammonoids

506 and foraminifera), and the lithologic changes.

507 The ammonoid zonation of the Jebel Oust section was made by Memmi (1981, 1989); it is not

508 complete for some intervals as some zones were not recognized by the author and the

509 boundaries between some zones are not defined. Memmi (1989, p. 64) underlined that her

510 zonal scheme is based on the zonation established for SE France and SE Spain; however she

511 quoted authors who have worked on the Tithonian to lowermost Hauterivian. For the

512 Hautervian, it seems that Memmi (1989) mainly used the zonal scheme established by

513 Moullade and Thieuloy (1967) and Thieuloy (1977) for SE France; the correlation between

514 this former zonal scheme and a more recent version is established by Bulot et al. (1993; their

515 Table 1). Memmi (1989) replaced the A. radiatus Zone by the Breistrofferella castellanensis

516 Zone used by Company (1987). Her zonal scheme included the J. jeannoti Zone, now

517 considered as the second subzone of the C. loryi Zone in the standard zonation (Reboulet et

518 al., 2018). Memmi (1989) considered that the S. sayni and P. ligatus Zones should be

519 separated but the author grouped them as she was not able to distinguish them in the Jebel

520 Oust section, and also in other northern Tunisian sections (see Memmi, 1981, 1989). For the

521 uppermost Hauterivian, Memmi $(1981,1989)$ considered the "Balearites balearis-

522 Pseudothurmannia angulicostata Zone". For this interval, she recognized in some sections (as

523 Jebel Bou Kornine) ammonoid assemblages with both index-species and also "Crioceratites 
524 krenkeli and Pseudothurmannia mortilleti". The B. balearis Zone was introduced by

525 Busnardo (1984). In Ben Haj Ali and Memmi (2013), the Hauterivian zonal scheme of

526 Memmi (1989) was slightly modified with the introduction of the B. balearis Zone; however,

527 the B. castellanensis Zone and the S. sayni-P. ligatus Zone are kept. For the lower Barremian,

528 Memmi (1989) did not use the zonal scheme established by Busnardo (1965; see also Sornay,

529 1977; Roger, 1980) for the stratotype of Angles section (France) and she replaced the

530 "Nicklesia pulchella Zone" by her "Holcodiscus caillaudi Zone". For the upper Barremian,

531 Memmi (1989) used the "Silesites seranonis-Barremites strettostoma Zone" that corresponds

532 to the "Silesites seranonis Zone" of Busnardo (1965). This latter author subdived this zone in

533 three subzones recognized by Memmi (1989) in the Jebel Oust section. For the northern

534 Tunisia, Ben Haj Ali and Memmi (2013) used the Barremian zonal scheme of Memmi (1989).

535 Ammonoid taxa with a biostratigraphic interest for the Jebel Oust locality have been reported

536 on the redrawn section (Fig. 13). Unfortunately, it was impossible to check the identifications

537 of this material; the ammonoids studied by Memmi (1989) are not illustrated, except for few

538 taxa occurring around the lower-upper Valanginian and Valanginian-Hauterivian boundaries

539 (Memmi, 1965, 1970, 1973) and, for the moment, the Memmi's collection is not accessible.

541 The interval around the Valanginian-Hauterivian boundary in the Jebel Oust section is

542 relatively well characterized by assemblages allowing to Memmi (1989) to define the

543 uppermost zone of the Valanginian, the "Teschenites callidiscus Zone" (= T. callidiscus

544 Subzone of the $C$. furcillata Zone in the standard zonation), and the first zone of the

545 Hauterivian, the "B. castellanensis Zone" (= A. radiatus Zone in the standard zonation). Even

546 if this latter index-species has not been found, Memmi (1989) put the base of the Hauterivian

547 stage at the first bed of Formation 5 (but no ammonoid sampled in this bed; Fig. 13). The

548 genus Oosterella is well represented around the boundary and Busnardo and Memmi (1972) 
549 defined a "Oosterella interval" corresponding to Formations 4e, 5 to 7 (see also Memmi and

550 Maamouri, 1974; Memmi, 1981, 1989; Maamouri et al., 1994). In SE France, oosterellids are

551 more represented in the upper Valanginian but they also occur in the lowermost Hauterivian

552 (mainly in the A. radiatus Zone; Reboulet, 1996, and references therein). The LO of $P$.

553 infundibulum is recorded at the top of Formation 5 of the Jebel Oust section; Memmi (1989,

554 p. 71) suggested that the LO of this species could be in her " $B$. castellanensis Zone". In SE

555 France, the same observation is made and the LO of $P$. infundibulum is recorded in the upper 556 part of the A. radiatus Zone (Reboulet, 1996). The correlative datum (key horizon) for the

557 Jebel Boulahouajeb and Jebel Oust sections is placed at the base of bed JBH-B7 (near the

558 base of the calcareous bundle H1) and the first bed of Formation 5, respectively.

559

560 The C. loryi Zone was not recognized in the Jebel Oust section (Memmi, 1989). The author 561 underlined (p. 46 and 72) that a fault occurs between the formations 7 (" $B$. castellanensis 562 Zone”) and 8 (“Olcostephanus (Jeannoticeras) jeannoti Zone”). In the current standard 563 zonation, J. jeannoti is the index-species of the second subzone of the C. loryi Zone. In SE

564 France, the LO of J. jeannoti is in the upper part of the C. loryi Zone and its HO is in the 565 lowermost part of the L. nodosoplicatum Zone (Bulot et al., 1993; Reboulet, 1996; Reboulet 566 and Atrops, 1999). Consequently, the lower part of Formation 8 of the Jebel Oust section in 567 which J. jeannoti occurs is correlated with the upper part of the C. loryi Zone and the 568 lowermost part of the L. nodosoplicatum Zone of the Jebel Boulahouajeb section where J. 569 jeannoti has been also found (beds JBH-B20 and B21); thus, the upper part of Formation 8 570 should belong to the L. nodosoplicatum Zone (see below).

572 The L. nodosoplicatum Zone was not clairly identified in the Jebel Oust section; this zone was 573 not separated from the S. sayni and P. ligatus Zones. Memmi (1989) probably used these 
574 zones sensu Moullade and Thieuloy (1967) or sensu Thieuloy (1977). Bulot et al. (1993, p.

575 46) recognized two successive populations of Subsaynella: S. sayni and Subsaynella mimica 576 (see also Thieuloy and Bulot, 1993). In the first interval, they identified an assemblage made 577 of "true" S. sayni, Cruasiceras cruasense and Abrytusites juliani. Consequently, the base of 578 the S. sayni Zone sensu Bulot et al. (1993) was lowered and C. cruasense became the index579 species of the first horizon of this zone; these authors underlined (p. 50) that S. mimica, 580 classically identified to $S$. sayni, was considered in literature as the index-species to place the 581 base of the S. sayni auctorum Zone (see Moullade and Thieuloy, 1967; Busnardo, 1984;

582 Hoedemaecker et al, 1990). In the second interval, Bulot et al. (1993) identified an 583 assemblage characterized by $S$. mimica (= S. sayni auctorum), P. ligatus sensu stricto (= sensu 584 d'Orbigny; not sensu Moullade and Thieuloy, 1967) and S. rotula. Thus, the base of the $P$. 585 ligatus Zone sensu Bulot et al. (1993) was lowered and its top was defined by the LO of $B$. 586 balearis; $P$. ligatus sensu lato (= sensu Moullade and Thieuloy, 1967) occurs higher in the $P$. 587 ligatus Zone sensu Bulot et al., 1993).

588 Among ammonoids found by Memmi (1989) in the lowermost part of Formation 9, there are 589 “Neocomites gr. nodosoplicatus", S. sayni, Abrytusites juliani, P. ligatus and Spitidiscus 590 rotula. This author probably used the occurrence of "Neocomites gr. nodosoplicatus" to 591 characterize the lower part of Formation 9 to the L. nodosoplicatum Zone. However, it is 592 difficult to use this assemblage of five taxa for correlations with the Jebel Boulahouajeb 593 section. Indeed, according to the stratigraphic distribution of ammonoids given by Bulot et al. 594 (1993) for the interval around the lower-upper Hauterivian boundary in SE France, all these 595 five species cannot co-occur together. A. juliani can be found with "true" S. sayni in the 596 lowermost part of the S. sayni Zone sensu Bulot et al. (1993), and S. rotula co-occurs with 597 "true" P. ligatus in the lower part of the P. ligatus Zone sensu Bulot et al. (1993). Therefore, 598 the identification of some species made by Memmi (1989) must be interpreted differently. As 
600 Bulot et al. (1993), it can be considered here that the specimen(s) identified by Memmi as " $N$. 601 gr. nodosoplicatus" could correspond to Lyticoceras claveli or Lyticoceras kiliani, that occur 602 in the upper part of this zone in SE France (Bulot et al., 1993; Bulot, 1995; Reboulet, 1996; 603 Reboulet and Atrops, 1999), or to C. cruasense, that occurs in the lower part of the S. sayni 604 Zone in SE France (Bulot et al., 1993; Bulot, 1995). In this case, P. ligatus and S. rotula were 605 probably also misidentified at the specific level (the identification of these taxa is difficult, 606 more particularly to distinguish the different species of Plesiospitidiscus). Consequently, 607 according to this new interpretation, the lower part of Formation 9 in the Jebel Oust section 608 could belong to the S. sayni Zone. However, the lowermost part of Formation 9 could belong 609 to the L. nodosoplicatum Zone as the assemblage described by Memmi (1989) is located 610 around 35 meters above the base of this formation. For this reason, the stratigraphic interval 611 corresponding to the upper part of Formation 8 and lower part of Formation 9 is correlated 612 with the calcareous bundle $\mathrm{H} 2$ of the Jebel Boulahouajeb section in which the boundary 613 between the L. nodosoplicatum and S. sayni Zones is placed (at the top of JBH-B30). This 614 correlation is also supported by the lithologic change observed above; from the base to the top 615 of Formation 9 of the Jebel Oust section, the sedimentation becomes more marly as observed 616 in the Jebel Boulahouajeb section (between beds JBH-B32 and B86). It is interesting to note 617 that in SE France (Vocontian basin), the limestone-marl alternations are mainly characterized 618 by thick calcareous beds and thinner marly interbeds in the lower Hauterivian, and it is the 619 opposite in the lower part of the upper Hauterivian for which marly interbeds are generally 620 thicker, with relatively thin calcareous beds in the S. sayni Zone (see Ferry and Rubino, 1987; 621 Bulot, 1995; Reboulet, 1996). 
623 In all sections studied by Memmi (1989), the S. sayni and P. ligatus Zones have not been

624 separated. The author (p. 72) underlined that both index-species have been found in same 625 beds, as recorded in the uppermost part of Formation 9 at Jebel Oust (Fig. 13) and she 626 suggested that a condensation cannot be excluded. This hypothesis appears unlikely for most 627 of northeastern Tunisian sections, often characetrized by dilated series. A misidentification of 628 some taxa could be an alternative; thus, new interpertations of identification can be proposed 629 here for the specimens located in the uppermost part of Formation 9 and three biostratigraphic 630 implications can be evoked as follows (a to c). a) If the identification of S. sayni made by 631 Memmi (1989) is correct, that of P. ligatus is wrong (see above); in this case, this interval 632 could correspond to the $S$. sayni Zone (its upper part). b) If her identification of $P$. ligatus is 633 correct, the specimen(s) identified as S. sayni by Memmi (1989) could be interpreted here as 634 S. mimica (see above), for which the LO is in the upper part of the S. sayni Zone sensu Bulot 635 et al. (1993) and its HO is in the lower part of the P. ligatus Zone sensu Bulot et al. (1993) in 636 SE France (Bulot et al., 1993; Bulot, 1995). Consequently, the uppermost part of Formation 9 637 (represented by two thick calcareous beds) could belong to the lower part of the P. ligatus 638 Zone and the base of this calcareous interval could be correlated with the base of bed JBH639 B86 in the Jebel Boulahouajeb section where the sedimentation becomes more calcareous 640 (bundle H3). c) The specimens of S. sayni located in the uppermost part of Formation 9 could 641 belong to Discoidellia. Indeed, Vermeulen (1998) evoked the great morphological affinities 642 between some species of Discoidellia and Subsaynella, and their phyletic relation. Taking into 643 account the stratigraphic distribution of Discoidellia (Vermeulen, 1995, 1999), this genus can 644 occur in the B. balearis Zone with Plesiospitidiscus. The specimen(s) of P. ligatus occuring in 645 the uppermost part of Formation 9 can be correspond to the P. ligatus sensu lato, for which 646 the distribution ends in the lowermost part of the B. balearis Zone according to Bulot et al. 647 (1993). These ammonites could be also misidentified and could correspond to $P$. subdifficilis 
648 that occur in the B. balearis Zone (Figs. 3b and 13). Consequently, the couple of calcareous

649 beds located in the uppermost part of Formation 9 could belong to the lower part of the $B$.

650 balearis Zone and could be correlated with the couple of calcareous beds JBH-B163 and

651 B170 (bundle H4). In this case, the lithologic changes seem more similar in both sections than

652 those observed in the previous attemp of correlations.

653

654 Memmi $(1981,1989)$ has not used the B. balearis Zone in her zonal scheme of the 655 northeastern Tunisian area; she considered the "B. balearis-P. angulicostata Zone" (see 656 above). In the zonation of the Jebel Oust section, Memmi (1989) indicated the " $P$.

657 angulicostata Zone" (= P. ohmi Zone in the standard zonation) for Formation 11 in which she

658 found the index-species and $P$. mortilleti. This allows to correlate the couple of calcareous

659 beds of this formation with the couple of calcareous beds JBH-B202 and B219 of the Jebel

660 Boulahouajeb section as this bundle H5 mainly belongs to the P. mortilleti Subzone.

661 Consequently, Formation 10 (no ammonoid sampling) is correlated with the interval

662 belonging to the B. balearis Zone in the Jebel Boulahouajeb section.

663 Above the calcareous bundle of the P. ohmi Zone, the sedimentation becomes more

664 argillaceous and a thick marly interval occurs in both sections. In the Jebel Boulahouajeb

665 section, the Hautervian-Barremian boundary is placed in the uppermost part of this interval

666 (bed JBH-B232 corresponding to the base of T. hugii Zone), while Memmi (1989) placed this

667 boundary at the base of Formation 12 . The author indicated the " $H$. caillaudi Zone" for this

668 formation despite the lack of the index-species. Memmi (1989) underlined that the

669 assemblage of this zone is very poor; among few identified taxa, she recognized the genus

670 Valdedorsella. In the Jebel Boulahouajeb section, the LO of Valdedorsella? uhligi is at the top

671 of $P$. mortilleti Subzone (top of the calcareous bundle H5). So, the Barremian age of

672 Formation 12 of the Jebel Oust section is probably given by the planktic foraminiferal 
673 Hedbergella sigali Zone reported by Memmi and Maamouri (1974), and Memmi (1989).

674 Classically, this zone is considered as the first zone of the Barremian in Tunisia (see above

675 and Ben Haj Ali, 2005), but some authors as Coccioni and Premoli-Silva (1994) and Premoli-

676 Silva et al. (2017) have recorded this index-species in the Valanginian and Hauterivian of SE

677 Spain. Consequently, Formation 12 could belong to the uppermost Hauterivian (P. picteti

678 Subzone) considering that the base of Barremian is put at the base of bed JBH-B232 with the

679 LO of A. intermedius. It can be added that the upper part of Formation 12 could correspond to 680 the lowermost Barremian in the case of the Hauterivian-Barremian boundary at the Jebel

681 Boulahouajeb section could be lowered at the level JBH-B221 where the LO of P. sigali is 682 observed (see part 5.1).

683

684 In the Jebel Oust section, Formation 13 (around $100 \mathrm{~m}$ in thickness, mainly represented by

685 thick calcareous beds) corresponds to the Barremian bundle of the literature ("Barre

686 barrémienne", Memmi, 1981, 1989). According to this author, it is placed in the

687 "Hemihoplites feraudi Subzone" of the "Silesites seranonis-Barremites strettostoma Zone"

688 (upper Barremian), even if these index-species have not been found in this part of the section.

689 The author found only two species of ammonoids: "Silesites vulpes" and "Ancyloceras

690 trispinosum" (see Fig. 12 in Memmi, 1989). In the Jebel Boulahouajeb section, there is also a

691 thick calcareous bundle (around $200 \mathrm{~m}$ of limestone-marl alternations; only the first beds are

692 represented here) that could be correlated with Formation 13. The zonal scheme is not

693 established for this calcareous bundle of the Jebel Boulahouajeb section; only the basal part of

694 this interval belongs to the lower Barremian (bed JBH-B232 and above).

695

696 In comparaison with the Jebel Oust section, the study of the Jebel Boulahouajeb section 697 provided a more detailed lithological succession of the uppermost Valanginian-lowermost 
698 Barremian interval of the northern Tunisia, a more complete sampling of macrofauna, a

699 greater set of data on the ammonoid distributions and assemblages, and a greater illustration

700 of this fauna. Contrary to the Jebel Oust section where the boundaries between several

701 ammonoid zones were not identified, the work on the Jebel Boulahouajeb section allowed to

702 update the zonal scheme for the north Tunisia with the recognition of most of the zones of the

703 standard zonation (Mediterranean Province; see Reboulet et al., 2018). Consequently, it

704 appears that the Jebel Boulahouajeb section could be considered as a good reference section 705 for the Tunisian trough, at least for the Hauterivian interval.

706

\section{6. Conclusion}

708 The study of ammonoids and foraminifera from the uppermost Valanginian to lowermost

709 Barremian of the Jebel Boulahouajeb section of the northern Tunisia has led to three majors

710 results.

711 1- Most of the ammonoid zones of the standard zonation (Mediterranean Province) have been

712 identified and well characterized by their diversified assemblages: for the uppermost

713 Valanginian, $C$. furcilla Zone; for the lower Hauterivian, A. radiatus, $C$. loryi and $L$.

714 nodosoplicatum Zones; for the upper Hauterivian, B. balearis and P. ohmi Zones (with their

715 subdivisions in four and three subzones, respectively); for the lowermost Barremian, T. hugii

716 Zone. The S. sayni and P. ligatus Zones have not been recognized as the lower part of the

717 upper Hauterivian has not been sampled for macrofauna.

718 2- The planktic foraminiferal fauna, observed only in the upper Hauterivian and lowermost

719 Barremian, is poorly diversified. Distributions of some species are similar to those recorded in

720 some previous studies done in Tunisia, but not in accordance with data from other Tethyan

721 areas. 
722 3- Correlations between the Jebel Boulahouajeb and Jebel Oust sections are proposed using

723 mainly the ammonoid zonal schemes. The Jebel Boulahouajeb section has to be considered

724 more complete in the lithologic succession, and in the distributions and assemblages of

725 ammonoids. Therefore, it could be a new reference section of the Tunisia trough for the

726 studied interval (mainly Hauterivian).

\section{Acknowledgements}

729 Lucia Memmi, deceased in 2015, was geologist at the "Office National des Mines" of Tunisia.

730 She worked on the preliminary study of the macrofauna of the Jebel Boulahouajeb section

731 during the Master of Melliti (2012; university of Tunis). The authors acknowledge Professor

732 Miguel Company (University of Granada, Spain) for his point of view on the identification of 733 several ammonoid specimens and his helpful comments on the script. We are grateful to

734 Natalie Caughtry (stratigrapher, geoconsulting CGG, United Kingdom) for correcting the

735 English. We thank the reviewers Mohamed Benzaggagh (University of Moulay Ismail,

736 Morocco) and Ignacio Arenillas (University of Zaragoza, Spain) for their comments, and

737 Damien Delvaux for his editorial assistance.

738

739 References

740

741 Avram, E., 1995. Representatives of the Family Holcodiscidae SPATH, 1924 (Ammonitina) in

742 Romania. Memorie Descrittive Della Carta Geologica d'Italia 51: 11-45.

744 Ben Abdesselam-Mahdaoui, S., Benzaggagh, M., Bouhlel, S., Razgallah, S., 2010. Nouvelles 
746 Campanien dans le secteur de Hammam Zriba-Jebel Guebli (Tunisie septentrionale). Revue

747 internationale de géologie, de géographie et d'écologie tropicales 1-2: 113-126.

749 Ben Abdesselam-Mahdaoui, S., Benzaggagh, M., Razgallah, S., Rebah, A., Rakia, B., 2011.

750 Les associations des calpionelles du Berriasien et du Valanginien inférieur de la Tunisie

751 septentrionale. Comparaison avec les associations du Rif externe (Maroc). Comptes Rendus 752 de l'Académie des Sciences, Palevol 10: 527-535.

753

754 Ben Ferjani, A., Burollet, P.F., Mejri, F., 1990. Petroleum geology of Tunisia. Entreprise 755 Tunisienne d'Activités Pétrolières, Tunis: 194 pp.

757 Ben Haj Ali, N., 2005. Les foraminifères planctoniques du Crétacé (Hauterivien à Turonien 758 inférieur) de Tunisie : systématique, biozonation et précisions stratigraphiques. Thèse de 759 Doctorat d'Etat Es-Sciences Géologiques, Université de Tunis El Manar: 348 pp.

761 Ben Haj Ali, N., 2006. Les foraminifères planctoniques du Crétacé inférieur de la Tunisie 762 septentrionale. International Conference on the Geology of the Arab World (GAW8), Cairo 763 University: 609-617.

764

765 Ben Haj Ali, N., 2008. Synthèse stratigraphique et nomenclature pour le Crétacé inférieur de 766 la Tunisie septentrionale. Notes du Service Géologique de Tunisie 76: 149-161.

768 Ben Haj Ali, N., Memmi, L., 2013. Northern Tunisian Lower Cretaceous Stratigraphic 
770 Rocha, R., et al. (eds), Strati 2013, First International Congress on Stratigraphy, Lisboa,

771 Springer Geology: 643-647.

772

773 Ben Haj Ali, N., Ben Haj Ali, M., Dali, Taieb, Fakraoui, M., 1993. Le Crétacé inférieur de la

774 région du Krib : résultats biostratigraphiques et découpages lithologiques. Actes des $5^{\text {èmes }}$

775 journées de Géologie tunisiennes Tunis, 24-27 Juin 1993. Office National des Mines, Service

776 Géologique National: 9-27.

777

778 Bensalem, H., 2002. The Cretaceous-Paleogene transition in Tunisia: general overview.

779 Palaeogeography, Palaeoclimatology, Palaeoecology 178: 139-143.

780

781 Bobier, C., Viguier, C., Chaari, A., Chine, A., 1991. The post-Triassic sedimentary cover of

782 Tunisia: seismic sequences and structure. Tectonophysics 195: 371-410.

783

784 Bolze, J., Burollet, P.F., Castany, G., 1952. Le sillon tunisien. XIX ${ }^{\text {ème }}$ Congrès Géologique

785 International. Monographies régionales, $2^{\mathrm{ème}}$ série: Tunisie 5: 112 pp.

786

787 Bonnefous, J., 1972. Contribution à l'étude stratigraphique et micropaléontologique du

788 Jurassique de Tunisie (Tunisie septentrionale et centrale, Sahel et zones des Chotts). PhD

789 thesis, Université de Paris VI: 397 pp.

790

791 BouDagher-Fadel, M.K., Banner, F.T., Brown, P.R., Simmons, D., Gorbachick, T.N., 1995.

792 Gorbachikella from the Hauterivian, Barremian-Aptian of Tunisia. Revue de

793 Micropaléontologie 38: 179-193. 
795 Boughdiri, M., Sallouhi, H., Maâlaoui, K., Soussi, M., Cordey, F., 2006. Calpionellid 796 zonation of the Jurassic-Cretaceous transition in North-Atlasic Tunisia. Updated Upper 797 Jurassic stratigraphy of the "Tunisian trough" and regional correlations. Comptes Rendus 798 Geoscience 338: 1250-1259.

799

800 Bulot, L., 1995. Les formations à ammonites du Crétacé inférieur dans le Sud-Est de la France

801 (Berriasien à Hauterivien) : biostratigraphie, paléontologie et cycles sédimentaires.

802 Unpublished PhD thesis, Muséum National d'Histoire Naturelle, Paris: 398 pp.

803

804 Bulot, L.G., Thieuloy, J.P., Blanc, E., Klein, J., 1993. Le cadre stratigraphique du Valanginien 805 supérieur et de l'Hauterivien du Sud-Est de la France: définition de biochronozones et 806 caractérisation de nouveaux biohorizons. Géologie Alpine 68 (1992): 13-56.

807

808 Burollet, P.F., 1956. Contribution à l'étude stratigraphique de la Tunisie centrale. Annales des 809 Mines et de la Géologie, Tunis 18: 352 pp.

810

811 Burollet, P.F., 1991. Structures and tectonics of Tunisia. Tectonophysics 195: 359-369.

812

813 Busnardo, R., 1965. Rapport sur l'étage Barrémien. Colloque sur le Crétacé inférieur (Lyon,

814 septembre 1963). Mémoires du Bureau de Recherches Géologiques et Minières, Paris 34:

815 161-169.

816

817 Busnardo, R., 1984. Crétacé inférieur : échelles biostratigraphiques. In: Debrand Passard, S., 818 et al. (eds): Synthèse géologique du Sud-Est de la France. Mémoires du Bureau de 819 Recherches Géologiques et Minières, Paris 125: 291-294. 
821 Busnardo, R., Memmi, L., 1972. La série infracrétacée du Djebel Oust (Tunisie). Notes du

822 Service Géologique de Tunisie 38: 49-61.

823

824 Busnardo, R., Charollais, J., Weidmann, M., Clavel, B., 2003. Le Crétacé inférieur de la

825 Veveyse de Châtel (Ultrahelvétique des Préalpes externes; canton de Fribourg, Suisse). Revue 826 de Paléobiologie 22: 1-174.

827

828 Caron, M., 1985. Cretaceous planktonic foraminifera. In: Bolli, H.M., Saunders J.B., Perch-

829 Nielsen, K. (eds)., Plankton Stratigraphy, Cambridge University Press, Cambridge: 17-86.

830

831 Castany, G., 1951. Etude géologique de l'Atlas tunisien oriental. Annales des Mines et de la 832 Géologie, Tunis 8: $611 \mathrm{pp}$.

833

834 Cecca, F., Faraoni, P., Marini, A., 1998. Latest Hauterivian (Early Cretaceous) ammonites

835 from Umbria-Marche Apennines (Central Italy). Palaeontographia Italica 85: 61-110.

836

837 Cecca, F., Pallini, G., Erba, E., Premoli-Silva, I., Coccioni, R., 1994. Hauterivian-Barremian 838 chronostratigraphy based on ammonites, nannofossils, planktonic foraminifera and magnetic 839 chrons from the Mediterranean domain. Cretaceous Research 15: 457-467.

841 Chikhaoui, M., Maamouri, A.L., Salaj, J., Moncef Turki, M., Saadi, J., Ben Youssef, M.

842 Ghanmi, M., Zarbout, M., 1998. Blocs basculés au Crétacé inférieur dans la région du Kef

843 (Tunisie nord-occidentale). Compte Rendus de l'Académie des Sciences de Paris, Sciences de 844 la Terre et des planètes 327: 265-270. 
846 Coccioni, R., Premoli-Silva, I., 1994. Planktonic foraminifera from the Lower Cretaceous of

847 Río Argos sections (southern Spain) and biostratigraphic implications. Cretaceous Research

848 15: 645-687.

849

850 Company, M., 1987. Los ammonites del Valanginiense del sector oriental de las Cordilleras

851 Béticas (SE de España). Tesis Doctoral, Universidad de Granada, Granada, 294 pp.

852

853 Company, M., Sandoval, J., Tavera, J.M., 2003. Ammonite biostratigraphy of the uppermost

854 Hauterivian in the Betic Cordillera (SE Spain). Geobios 36, 685-694.

855

856 Company, M., Aguado, R., Sandoval, J., Tavera, J.M., Jiménez de Cisneros, C., Vera, J.A.,

857 2005. Biotic changes linked to a minor anoxic event (Faraoni Level, latest Hauterivian, Early

858 Cretaceous). Palaeogeography, Palaeoclimatology, Palaeoecology 224, 186-199.

860 Donze, P., Le Hégarat, G., Memmi, L., 1975. Les formations de la limite Jurassique-Crétacé

861 en Tunisie septentrionale (Djebel Oust). Série lithologique ; résultats biostratigraphiques et

862 paléogéographiques d'après les ammonites, les calpionelles et les ostracodes. Geobios 8: 147863151.

865 Ettachfini, M., 2004. Les ammonites néocomiennes dans l'Atlas atlantique (Maroc) :

866 biostratigraphie, paléontologie, paléobiogéographie et paléoécologie. Strata 2 (43): 1-225.

868 Ferry, S., Rubino, J.L., 1987. La modulation eustatique du signal orbital dans les sediments 869 pélagiques. Comptes Rendus de l'Académie des Sciences de Paris 305: 477-482. 
871 Hoedemaeker, P.J., 1995. Ammonite distribution around the Hauterivian-Barremian boundary

872 along the Río Argos (Caravaca, SE Spain). Géologie Alpine, Mémoire Hors Série 20 (1994):

$873219-277$.

874

875 Hoedemaeker, P., 2013. Genus Pseudothurmannia Spath, 1923 and related subgenera

876 Crioceratites (Balearites) Sarkar, 1954 and C. (Binelliceras) Sarkar, 1977 (Lower Cretaceous

877 Ammonoidea). Revue de Paléobiologie 32: 1-209.

878

879 Hoedemaeker, P.J., Bulot, L. (reporters), Avram, E., Busnardo, R., Company, M., Delanoy,

880 G., Kakabadze, M., Kotetishvilli, E., Krishna, J., Kvantaliani, I., Latil, J.L., Memmi, L.,

881 Rawson, P.F., Sandoval, J., Tavera, J.M. , Thieuloy, J.P., Thomel, G., Vašíček, Z.,

882 Vermeulen, J., 1990. Preliminary ammonite zonation for the Lower Cretaceous of the

883 Mediterranean region. Géologie Alpine 66: 123-127.

884

885 Hoedemaeker, P.J., Reboulet, S., (reporters), Aguirre-Urreta, M.B., Alsen, P., Aoutem, M.,

886 Atrops, F., Barragan, R., Company, M., González Arreola, C., Klein, J., Lukeneder, A., Ploch,

887 I., Raisossadat, N., Rawson, P.F., Ropolo, P., Vašíček, Z., Vermeulen, J., Wippich M.G.E.,

888 2003. Report on the $1^{\text {st }}$ International Workshop of the IUGS Lower Cretaceous Ammonite

889 Working Group, the "Kilian Group” (Lyon, 11 July 2002). Cretaceous Research 24, 89-94,

890 and erratum (p. 805).

891

892 Holbourn, A.E.L., Kaminski, M.A., 1995. Valanginian to Barremian benthic foraminifera

893 from ODP Site 766 (Leg 123, Indian Ocean). Micropaleontology 41: 197-250. 
Jauzein, A., 1967. Contribution à l'Etude Géologique des Confins de la Dorsale Tunisienne

896 (Tunisie septentrionale). Annales des Mines et de la Géologie, Tunis 22: 475 pp.

897

898 Kamoun, F., Peybernès, B., Ciszak, R., Calzada, S., 2001. Triassic palaeogeography of

899 Tunisia. Palaeogeography, Palaeoclimatology, Palaeoecology 172: 223-242.

900

901 Klein, J., 2005. Lower Cretaceous Ammonites I, Perisphinctaceae 1: Himalayitidae,

902 Olcostephanidae, Holcodiscidae, Neocomitidae, Oosterellidae. In: Riegraf, W. (Ed.),

903 Fossilium Catalogus I: Animalia. Backhuys Publishers, Leiden, Netherlands, part 139, 484

904 pp.

905

906 Klein, J., Vašíček, Z., 2011. Lower Cretaceous Ammonites V, Desmoceratoidea. In: Riegraf,

907 W. (Ed.), Fossilium Catalogus I: Animalia, Backhuys-Margraf Publishers, Weikersheim,

908 Germany, Pars 148, 311 pp.

909

910 Klein, J., Busnardo, R., Company, M., Delanoy, G., Kakabadze, M., Reboulet, S., Ropolo, P.,

911 Vašíček, Z., Vermeulen, J., 2007. Lower Cretaceous Ammonites III. Bochianitoidea,

912 Protancyloceratoidea, Ancyloceratoidea, Ptychoceratoidea. In: Riegraf, W. (Ed.), Fossilium

913 Catalogus I: Animalia. Backhuys Publishers, Leiden, Netherlands, Pars 144, 381 pp.

914

915 Klein, J., Hoffmann, R., Joly, B., Shigeta, Y., Vašíček, Z., 2009. Lower Cretaceous

916 Ammonites IV. Boreophylloceratoidea, Phylloceratoidea, Lytoceratoidea, Tetragonitoidea,

917 Haploceratoidea including the Upper Cretaceous representatives. In: Riegraf, W. (Ed.),

918 Fossilium Catalogus I: Animalia. Backhuys Publishers, Leiden, Netherlands, Pars 146, 416

919 pp. 
921 Lehmann, J., Heldt, M., Bachmann, M., Negra, M.E.H., 2009. Aptian (Lower Cretaceous)

922 biostratigraphy and cephalopods from north central Tunisia. Cretaceous Research 30: 895923910.

925 Maamouri, A.L., Salaj, J., 1978. Subdivisions microbiostratigraphiques du Crétacé inférieur 926 du Djebel Oust (Tunisie septentrionale). Actes du VI Colloque Africain de Micropaléontlogie, 927 Tunis (1974). Annales des Mines et de la Géologie, Tunis 28: 91-101.

928

929 Maamouri, A.L., Salaj, J., Maamouri, M., Matmati, F., Zargouni, F., 1994. Le Crétacé 930 inférieur du Jebel Oust (Tunisie nord-orientale) : microstratigraphie - biozonation - aperçu 931 sédimentologique. Zemny plyn a nafta 39: 73-105.

932

933 Masrouhi, A., Bellier, O., Koyi, H., Vila, J.M., Ghanmi, M., 2013. The evolution of the 934 Lansarine-Baouala salt canopy in the North African Cretaceous passive margin in Tunisia. 935 Geological Magazine 150: 835-861.

936

937 Melliti, S., 2012. Stratigraphie et paléobiodiversité des séries du Crétacé inferieur de la chaîne 938 de Lansarine (Région de Tebourba). Unpublished Master report, Université de Tunis El 939 Manar, $134 \mathrm{pp}$.

940

941 Melliti, S., Ben Haj Ali, N., Memmi, L., Arfaoui, M.S., Zargouni, F., 2013. Upper

942 Valanginian-Hauterivian ammonites and foraminiferal assemblages in Boulahouajeb 943 (Lansarin Chain, Northeast Tunisia). Micropaleontology and the IODP: Past, Present and 944 Future Applications, book of abstracts. The Micropalaeontological Society Annual 
945 Conference, The Natural History Museum, London, 18th \& 19th November 2013. The

946 Micropalaeontological Society.

947

948 Memmi, L., 1965. Sur quelques ammonites du Valanginien de "l'Oued Guelta” (Tunisie).

949 Bulletin de la Société Géologique de France 7: 833-838.

950

951 Memmi, L., 1969. Eléments pour une biostratigraphie de l'Hauterivien du "Sillon Tunisien".

952 Notes du Service Géologique de Tunisie 31: 41-50.

953

954 Memmi, L., 1970. Remarques sur les Oosterella (Ammonoidea) du "sillon tunisien" oriental.

955 Bulletin de la Société Géologique de France 1: 146-150.

956

957 Memmi, L.,1973. Neohoploceras solignaci, Ammonite nouvelle de l'Hauterivien de Tunisie.

958 Annales des Mines et de la Géologie, Tunis 26: 229-303.

959

960 Memmi, L., 1979. Historique et actualisation du Crétacé inférieur de Tunisie septentrionale.

961 Notes du Service Géologique de Tunisie 45: 45-53.

962

963 Memmi, L., 1981. Biostratigraphie du Crétacé inférieur de la Tunisie nord-orientale. Bulletin

964 de la Société Géologique de France 23: 175-183.

965

966 Memmi, L., 1989. Le Crétacé inférieur (Berriasien-Aptien) de Tunisie. Biostratigraphie,

967 Paléogéographie et Paléoenvironnements. Thèse de Doctorat d'état Ès- Sciences, Université

968 de Lyon 1, 158 pp (Annexes, 286 pp). 
970 Memmi, L., Maamouri, A.L., 1974. Crétacé inférieur du Djebel Oust. In: Salaj et al., VI ${ }^{\mathrm{e}}$

971 Colloque Africain de Micropaléontologie, Livret-guide des excursions, Editions du Service

972 Géologique de Tunisie: 31-39.

973

974 Memmi, L., Salaj, J., 1975. Le Berriasien de Tunisie. Succession des faunes d'Ammonites, de

975 Foraminifères et de Tintinnoïdiens. Colloque sur la limite Jurassique-Crétacé, Lyon-

976 Neuchâtel, 1973. Mémoires du Bureau de Recherches Géologiques et Minières, Paris 86: 58-

97767.

978

979 Memmi, L., Donze, P., Combémorel, R., Le Hégarat, G., 1989. The transition from Jurassic to

980 Cretaceous in northeast Tunisia: biostratigraphic details and distribution of facies. Cretaceous

$981 \quad$ Research 10: 137-151.

982

983 Moullade, M., 1966. Etude stratigraphique et micropaléontologique du Crétacé inférieur de la

984 "fosse vocontienne". Documents des Laboratoires de Géologie de la Faculté des Sciences de 985 Lyon 15: 369 pp.

986

987 Moullade, M., 1974. Zones de Foraminifères du Crétacé inférieur mésogéen. Comptes Rendus 988 de l'Académie des Sciences, Paris 278: 1813-1816.

989

990 Moullade, M., Thieuloy, J.P., 1967. Les zones d'ammonites du Valanginien supérieur et de

991 l'Hauterivien vocontiens. Compte Rendu sommaires des Séances de la Société Géologique de 992 France 6: 228-230. 
994 Naji, C., Gharbi, M., Amri, Z., Masrouhi, A., Bellier, O., 2018a. Temporal and spatial

995 changes of the submarine Cretaceous paleoslope in Northern Tunisia, inferred from slump

996 folds analysis. Proceedings of the Geologists' Association 129: 40-56.

997

998 Naji, C., Masrouhi, A., Amri, Z., Gharbi, M., Bellier, O., 2018b. Cretaceous paleomargin

999 tilted blocks geometry in northern Tunisia: stratigraphic consideration and fault kinematic

1000 analysis. Arabian Journal of Geosciences 11: 583, https://doi.org/10.1007/s12517-018-3930-7

1001

1002 Neagu, T., 1975. Monographie de la faune des Foraminifères éocrétacés du couloir de la

1003 Dîmbovicioara, de Codlea et des Monts Persani (Couches de Carhaga). Mémoires de l'Institut 1004 de Géologie et Géophysique, Bucarest 25: 141 pp.

1005

1006 Perthuisot, V., 1981. Diapirism in Northern Tunisia. Journal of structural Geology 3: 2311007235.

1008

1009 Pervinquière, L., 1907. Etudes de paléontologie tunisienne. I. Cépahalopodes des terrains 1010 secondaires. De Rudeval F.R (Ed.), Paris: 438 pp.

1011

1012 Piqué, A., Tricart, P., Guiraud, R., Laville, E., Bouaziz, S., Amrhar, M., Ouali, R.A., 2002.

1013 The Mesozoic-Cenozoic Atlas belt (North Africa): an overview. Geodinamica Acta 15: 1851014208.

1015

1016 Premoli-Silva, I., Sliter, W.V., 2002. Practical manual of Cretaceous Planktonic foraminifera. 1017 In: Premoli-Silva, I. and Rettori, R. (eds), International School on Planktonic Foraminifera, $1^{\circ}$ 1018 course: Cretaceous, Perugia 18-22 February 2002 (Italy): 462 pp. 
1020 Premoli-Silva, I., Petrizzo, M.R., Soldan, D.M., 2017. Planktonic Foraminiferal Distribution 1021 From Upper Hauterivian-Lower Barremian Strata At Arroyo Gilico (Betic Cordillera, SE 1022 Spain): An Update. 10th International Symposium on the Cretaceous Vienna, August 21-26 1023 2017, Vienna (Austria), Berichte der Geologischen Bundesanstalt 120: 214.

Rais, J., Gaya, S., Alouani, R., Mouguina, E.M., Tlig, S., 1991. Le sillon tunisien : structuration synsédimentaire jurassique. Rift avorté et cicatrisé au Dogger supérieur-Malm, à 1027 la marge SE de la Téthys maghrébide. Comptes Rendus de l'Académie des Sciences, Paris 1028 312: 1169-1175.

1030 Reboulet, S., 1996. L'évolution des ammonites du Valanginien-Hauterivien inférieur du 1031 bassin vocontien et de la plate-forme provençal (S-E de la France) : relations avec la 1032 stratigraphie séquentielle et implications biostratigraphiques. Documents des Laboratoires de 1033 Géologie, Lyon 137: 1-371.

1035 Reboulet, S., 2007. Diversification des ammonoïdes hétéromorphes : l'exemple des 1036 Himantoceras. Evolution et changements paléoenvironnementaux au Valanginien. Bulletin 1037 annuel de l'Association Géologique Auboise 28: 13-35.

1039 Reboulet, S., 2008. Origination of Himantoceras (heteromorphic ammonoids) related to 1040 palaeoceanography and climatic changes during the Valanginian. $1^{\text {st }}$ International Meeting on 1041 Correlation of Cretaceous Micro- and Macrofossils, 16-18 April 2008, Vienna (Austria), 1042 Berichte der Geologischen Bundesanstalt 74: 89-91. 
1044 Reboulet, S., Atrops, F., 1999. Comments and proposals about the Valanginian-lower

1045 Hauterivian ammonite zonation of south-eastern France. Eclogae geologiae Helvetiae 92:

$1046 \quad 183-197$.

Reboulet, S., Atrops, F., Ferry, S., Schaaf, A., 1992: Renouvellement des ammonites en fosse 1049 vocontienne à la limite Valanginien-Hauterivien. Géobios 25: 469-476.

Reboulet, S., Szives, O. (reporters), Aguirre-Urreta, B., Barragán, R., Company, M., Frau, C.,

1054 International Meeting of the IUGS Lower Cretaceous Ammonite Working Group, the Kilian

1055 Group (Vienna, Austria, $20^{\text {th }}$ August 2017). Cretaceous Research 91: 100-110.

1056

Robaszynski, F., Caron, M., 1995. Foraminifères planctoniques du Crétacé : commentaire de la zonation Europe-Méditerranée. Bulletin de la Société Géologique de France 166: 681-692.

Roger, J., 1980. Barrémien. In: Cavalier, C. and Roger, J. (coord.), Les étages français et leurs stratotypes, Mémoire du Bureau de Recherches Géologiques et Minières, Paris 109: 106-111.

Salaj, J., 1980. Microbiostratigraphie du Crétacé et du Paléogène de la Tunisie septentrionale 1064 et orientale (Hypostratotypes tunisiens). Geologic Institute of Dionýz Štúr, Bratislava (Ed.), 1065 special publication: $238 \mathrm{pp}$.

1067 Salaj, J., 1984. Foraminifers and detailed microbiostratigraphy of the boundary beds of the 1068 lower Cretaceous stages in the Tunisian Atlas. Geologica Carpathica 35: 583-599. 
1070 Sigal, J., 1977. Essai de zonation du Crétacé méditerranéen à l'aide des foraminifères 1071 planctoniques. Géologie Méditerranéenne 4: 99-108.

1072

1073 Solignac, M., 1927. Etude géologique de la Tunisie septentrionale. Direction Générale des 1074 Travaux Publics, Service des Mines, Tunis: 756 pp.

1075

1076 Sornay, J., 1977. Barrémien. Lexique Stratigraphique International. Volume 8: Termes 1077 Stratigraphiques Majeurs. Union Internationale des Sciences Géologiques, Commission de 1078 Stratigraphie, Congrès Géologique International. Centre National de la Recherche 1079 Scientifique, Paris: 1-194.

1080

1081 Souquet, P., Peybernès, B., Saadi, J., Ben Youssef, M., Ghanmi, M., Zarbout, M., Chikhaoui, 1082 M., Kamoun, F., 1997. Séquences et cycles d'ordre 2 en régime extensif et transtensif : 1083 exemple du Crétacé inférieur de l'Atlas tunisien. Bulletin de la Société Géologique de France 1084 168: 373-386.

1085

1086 Soussi, M., Mangold, C., Enay, R., Boughdiri, M., Ben Ismail, M.H., 2000. Le Jurassique 1087 inférieur et moyen de la Tunisie septentrionale; corrélations avec l'axe Nord-Sud et 1088 paléogéographie. Geobios 33: 437-446.

1089

1090 Soussi, M., 2003. Nouvelle nomenclature lithostratigraphique «événementielle » pour le 1091 Jurassique de la Tunisie atlasique. Geobios 36: 761-773. 
1093 Stranik, Z., Mencik, E., Memmi, L., Salaj, J., 1974. Biostratigraphie du Crétacé inférieur de

1094 l'Atlas Tunisien oriental. Notes du Service Géologique de Tunisie 41: 65-85.

1095

1096 Thieuloy, J.P., 1977. Les ammonites boréales des formations néocomiennes du Sud-Est

1097 français (Province subméditerranéenne). Geobios 10: 395-461.

1098

1099 Thieuloy, J.P., Bulot, L., 1993. Ammonites du Crétacé inférieur du Sud-Est de la France : 1.

1100 Nouvelles espèces à valeur stratigraphique pour le Valanginien et l'Hauterivien. Géologie

1101 Alpine (1992) 68: 85-103.

1102

1103 Van Hinte, J.E., 1972. The Cretaceous time scale and planktonic foraminiferal zones.

1104 Proceedings Koninklijke Nederlandse Akademie van Wetenschappen 75: 1-8.

1105

1106 Vermeulen, J., 1995. Nouvelle tripartition de la famille des Pulchelliidae (Ammonoidea)

1107 illustrée par la description de trois espèces des Alpes de Haute Provence. Riviéra Scientifique 1108 12: 65-80.

1109

1110 Vermeulen, J., 1999. Sur quelques espèces de Pulchelliidae (Ammonoidea, Ammonitina) de

1111 l'Hauterivien et du Barrémien du Sud-Est de la France. Annales du Muséum d'Histoire

1112 Naturelle de Nice (1998) 13: 351-387.

1113

1114 Vermeulen, J., 2003. Etude stratigraphique et paléontologique de la famille des Pulchelliidae

1115 (Ammonoidea, Ammonitina, Endemocerataceae). Géologie Alpine Mémoire Hors Série 42

1116 (2002), 1-333. 
1118 Vermeulen, J., Klein, J., 2006. Endemocerataceae: Pulchelliidae. In: Riegraf, W. (Ed.),

1119 Fossilium Catalogus I: Animalia. Backhuys Publishers, Leiden, Netherlands, Pars 141, 1881120277.

1122 Vermeulen, J., Lazarin, P., Lépinay, P., Leroy, L., Mascarelli, E., Meister, C., Menkveld1123 Gfeller, U., 2012. Ammonites (Ancyloceratina, Turrilitina) nouvelles ou peu connues de 1124 l'Hauterivien supérieur. Annales du Muséum d'Histoire Naturelle de Nice 27, 271-318.

Vermeulen, J., Arnaud, H., Arnaud-Vanneau, A., Lahondere J.C., Lépinay, P., Massonnat, G., 2013. L'Hauterivien supérieur et le Barrémien inférieur de la région de Seynes et Belvézet 1128 (Gard). Annales du Muséum d'Histoire Naturelle de Nice 28: 1-16.

Zargouni, F., 1975. Etude géologique de la chaîne de Lansarine (région de Tébourba, Atlas tunisien). Unpublished PhD thesis, Université de Paris VI: 94 pp.

\section{Appendix 1 - Systematic of ammonoids}

1134 This appendix presents the list of ammonoid taxa found in the Jebel Boulahouajeb section; the 1135 index-species used for the zonation and other taxa evoked in the text have been added. The 1136 classification is mainly based on Klein (2005), Vermeulen and Klein (2006), Klein et al. 1137 (2007, 2009), and Klein and Vašíček (2011); some short comments are made for some taxa.

Perisphinctoidea STEInManN

Neocomitinae SALFELD

«Thurmanniceras » COSSMANN

«Thurmanniceras » pertransiens (SAYN)

Criosarasinella THIEULOY

Criosarasinella furcillata THIEULOY 
Himantoceras trinodosum THIEULOY

Himantoceras n. sp. 2; see Reboulet, 1996

Teschenites THIEULOY

Teschenites callidiscus (THIEULOY); included in Neocomites (Teschenites) by Klein (2005, p. 315)

Teschenites subflucticulus REBOULET; included in Neocomites (Teschenites) by Klein (2005, p. 320)

? Endemoceratinae SCHINDEWOLF

Acanthodiscus UhLIG

Acanthodiscus radiatus (BRUGUIERE)

Breistrofferella THIEULOY

Breistrofferella castellanensis (D'ORBIGNY)

Lyticoceras HYATT

Lyticoceras claveli BUSNARDO \& THIEULOY

Lyticoceras kiliani REBOULET \& ATROPS

Cruasiseras BUSNARDO

Cruasiseras cruasense TORCAPEL

Spitidiscinae VermeUlen \& THIEUloY

Jeanthieuloyites COOPER

Jeanthieuloyites keyserlingiformis AVRAM \& GRADINARU

Jeanthieuloyites quinquestriatus BESAIRIE

Jeanthieuloyites solignaci (MEMMI)

Spitidiscus KILIAN; this genus is included in Desmoceratidae by Busnardo et al., 2003 (p. 49)

Spitidiscus lorioli (KILIAN)

Spitidiscus meneghinii (RODIGHIERO)

Spitidiscus rawsoni BULOT

Spitidiscus rotula (SOWERBY)

Olcostephanidae HAUG

Olcostephaninae HAUG

Olcostephanus NEUMAYR

Olcostephanus densicostatus (WEGNER)

Olcostephanus variegatus PAQUIER

Oosterellidae BREISTROFFER

Oosterella KILIAN

Oosterella cultrata (D'ORBIGNY) 
Holcodiscidae SPATH

Taveraidiscus Vermeulen \& THIEULOY

Taveraidiscus hugii (OOSTER) Avramidiscus VERMEULEN

Holcodiscus UHLIG

Holcodiscus caillaudianus (D’ORBIGNY)

Desmoceratoidea VON ZITTEL

Barremitidae BRESKOVSKI

Abrytusites NIKOLOV \& BRESKOVSKI

Abrytusites neumeyri (HAUG)

Plesiospitidiscus BREISTROFFER

Plesiospitidiscus fasciger (THIEULOY)

Plesiospitidiscus ligatus (D’ORBIGNY)

Plesiospitidiscus subdifficilis (KARAKASCH)

Barremites KILIAN

$$
\text { Barremites cassida (RASPAIL) }
$$

Montanesiceras BRESKOVSKI

Montanesiceras dimboviciorense (BRESKOVSKI); Company et al. (2005) included this species in Barremites Valdedorsella BREISTROFFER

Valdedorsella ? uhligi (HAUG); Company et al. (2003) included this species in "Barremites"

Barremitites AVRAM

Barremitites strettostoma (UHLIG)

Silesitidae HYATT

Pulchelliioidea DouvILLE (for an alternative classification, see note 96, p. 188 in Vermeulen and Klein, 2006)

Pulchelliidae DOUVILLE

Buergliceratinae VERMEULEN

Discoidellia VERMEULEN 
Pulchelliinae DouviLlé

Nicklesia HYATT

Haploceratoidea VON ZITTEL

Haploceratidae VON ZITTEL

Neolissoceras SPATH

Neolissoceras grasianum (D'ORBIGNY)

Phylloceratoidea vON ZITTEL

Phylloceratidae VON ZITTEL

Phylloceratinae VON ZITTEL

Phylloceras (Hypophylloceras)

Phylloceras (Hypophylloceras) tethys (D'ORBIGNY)

Phylloceras (Hypophylloceras) ponticuli (RoussEAU)

Phyllopachyceratinae COLLIGNON

Phyllopachyceras SPATH

Phyllopachyceras infundibulum (D'ORBIGNY)

Phyllopachyceras winkleri (UHLIG)

Lytoceratoidea NEUMAYR

Lytoceratidae NEUMAYR

Lytoceratinae NEUMAYR

Lytoceras SUESS

Lytoceras subfimbriatum (D'ORBIGNY)

Ancyloceratoidea GILL

Balearites balearis (NOLAN)

Balearites binelli (ASTIER); included in Binelliceras by Klein et al., 2007 (p. 50)

Balearites krenkeli (SARKAR); included in Crioceratites by Klein et al., 2007 (p. 42) 
Pseudothurmannia mortilleti (PICTET \& DE LORIOL); in view of Company et al. (2003), P. mortilleti is here considered as a senior synonym of $P$. catulloi (Parona)

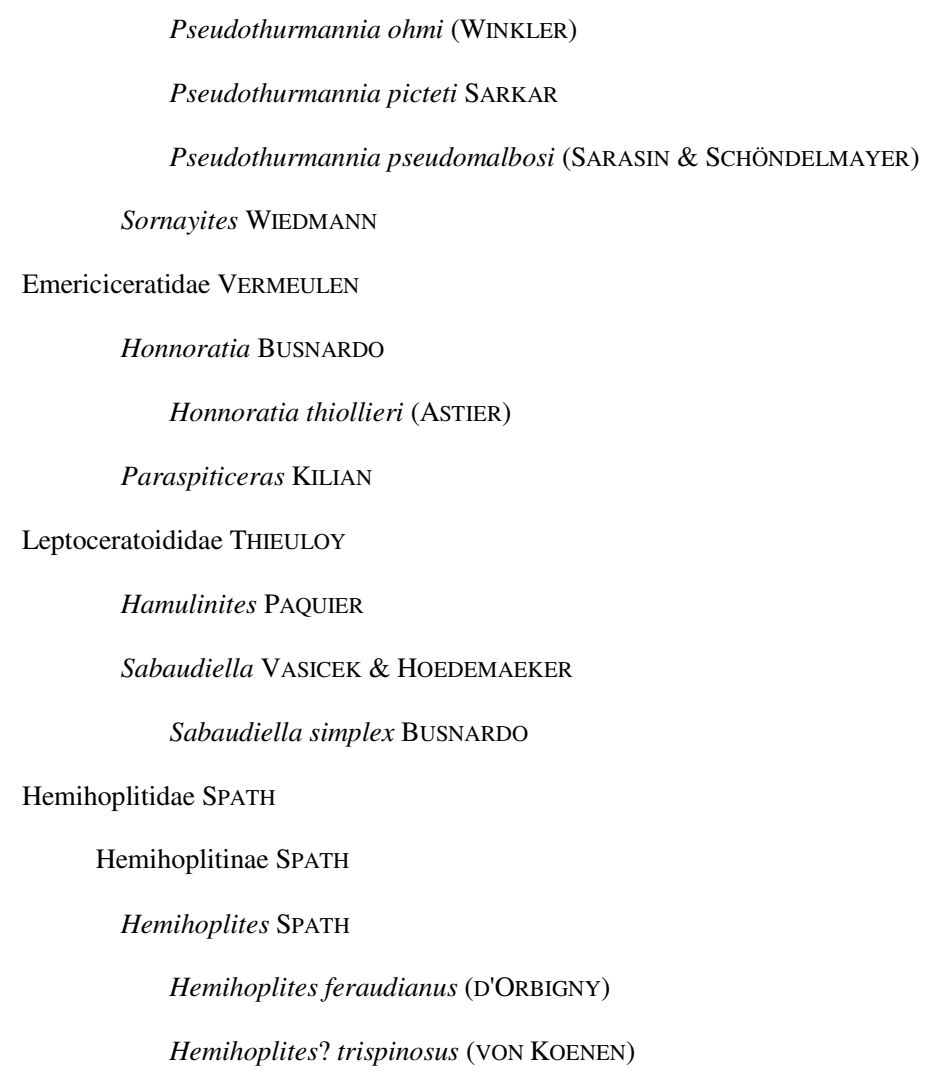

\section{Appendix 2 - Systematic of foraminifera}

\section{Alphabetic planktic foraminifera list}

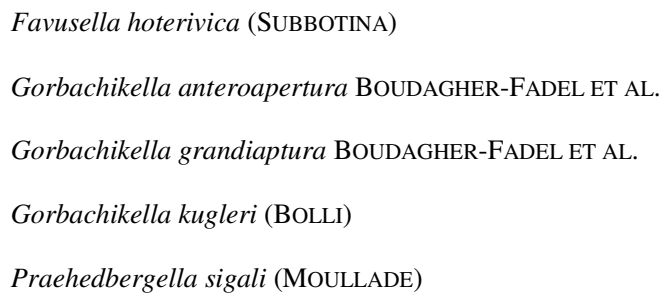




\section{Alphabetic benthic foraminifera list}

1297

1298

1299

1300

1301

1302

1303

1304

1305

1306

1307

1308

1309

1310

1311

1312

1313

1314

1315

1316

1317

1318

1319

1320

1321

1322

1323

1324

1325

1326

1327

1328

1329

1330

1331

1332
Ammodiscus cretaceus (REUSS)

Bathysiphon brosgei TAPPAN

Catharina sp.

Dentalina deflexa GRZYBOWSKI

Dentalina ejuncida LOEBLICH \& TAPPAN

Dentalina gracilis D'ORBIGNY

Dentalina oligostegia (REUSS)

Dorothia gradata (BERTHELIN)

Dorothia hauteriviana (MOULLADE)

Dorothia kummi (ZEDLER)

Dorothia lilliformis (BERTHELIN)

Dorothia ouachensis (SIGAL)

Dorothia oxycona (REUSS)

Dorothia hechti DIENI \& MASSARI

Dorothia praehauteriviana DIENI \& MASSARI

Dorothia zedlerae MOULLADE

Frondicularia hastata ROEMER

Gavelinella barremiana BETTENSTAEDT

Lenticulina eichenbergi BARTENSTEIN \& BRAND

Lenticulina heiermanni BETTENSTAEDT

Lenticulina multicella BARTENSTEIN, BETTENSTAEDT \& BOLLI

Lenticulina nodosa (REUSS)

Lenticulina ouachensis (SIGAL)

Lenticulina roemeri (REUSS)

Lenticulina rotulata LAMARCK

Marginulina planiscula (REUSS)

Marginulina striatocostata REUSS

Marginulinopsis.sp.

Marsonella kummi ZEDLER

Nodosaridea sp.

Nodosaria detruncata SCHWAGER

Planularia complanata (REUSS)

Ramulina sp.

Rhizammina sp.

Spirillina minima SCHACKO

Spirillina neocomiana MoULLADE 
1334 Figure captions

1335 Fig. 1. Geographic map of north Tunisia with location of the Jebel Boulahouajeb and Jebel 1336 Oust sections.

1338 Fig. 2. Jebel Boulahouajeb section (section JBH-A), Tunisia, lithology and ammonoid 1339 distribution; upper Valanginian stage (Criosarasinella furcillata Zone p.p.).

1341 Fig. 3. Jebel Boulahouajeb section (section JBH-B), Tunisia, lithology and ammonoid 1342 distribution; Fig. 3a: Hauterivian stage (from Acanthodiscus radiatus Zone to 1343 Plesiospitidiscus ligatus Zone p.p.) and its lower boundary (Valanginian Criosarasinella 1344 furcillata Zone p.p. recognized); Fig. 3b: Hauterivian stage (from P. ligatus Zone p.p to 1345 Pseudothurmannia ohmi Zone) and its upper boundary (Barremian Taveraidiscus hugii Zone 1346 p.p. recognized). Abbreviations: up. Val.: upper Valanginian; Bar.: Barremian; H1 to H5: 1347 calcareous bundles (limestone-dominated intervals separated by thick marly-dominated 1348 intervals).

Fig. 4. Ammonoids from the Jebel Boulahouajeb section (sections JBH-A and JBH-B), 1351 Tunisia. Scale bar: $1 \mathrm{~cm}$; black arrow: end of phragmocone; SC: Silicone cast. A, Lyticoceras 1352 sp. ind., JBH-B20, Lyticoceras nodosoplicatum Zone. B, Lyticoceras sp. ind., JBH-B24, L. 1353 nodosoplicatum Zone. C, Teschenites subflucticulus, JBH-A5, Criosarasinella furcillata 1354 Zone. D, Jeanthieuloyites keyserlingiformis, JBH-A2, C. furcillata Zone. E, Jeanthieuloyites 1355 quinquestriatus, JBH-A7, C. furcillata Zone. F, G, Jeanthieuloyites solignaci, JBH-A7, C. 1356 furcillata Zone. H, I, Spitidiscus lorioli, JBH-B9, Acanthodiscus radiatus Zone. J (SC), K 1357 (SC), Spitidiscus meneghini, JBH-B10, A. radiatus Zone. L (SC), Spitidiscus meneghini, 
1358 JBH-B11, A. radiatus Zone. M, Spitidiscus rawsoni, JBH-B30, L. nodosoplicatum Zone. N

1359 (SC), Himantoceras cf. trinodosum, JBH-B4, C. furcillata Zone.

1360

1361 Fig. 5. Ammonoids from the Jebel Boulahouajeb section (sections JBH-A and JBH-B),

1362 Tunisia. Scale bar: $1 \mathrm{~cm}$; black arrow: end of phragmocone; SC: Silicone cast. A,

1363 Olcostephanus densicostatus, JBH-A5, Criosarasinella furcillata Zone. B, Olcostephanus

1364 densicostatus, JBH-A6, C. furcillata Zone. C, Jeannoticeras jeannoti, JBH-B20, Lyticoceras

1365 nodosoplicatum Zone. D (SC), Oosterella ondulata, JBH-B6, C. furcillata Zone. E,

1366 Oosterella cultrata, JBH-B10, Acanthodiscus radiatus Zone.

1368 Fig. 6. Ammonoids from the Jebel Boulahouajeb section (section JBH-B), Tunisia. Scale bar:

$13691 \mathrm{~cm}$; black arrow: end of phragmocone; SC: Silicone cast. A (SC), Avramidiscus

1370 intermedius, JBH-B232, Taveraidiscus hugii Zone. B (SC), Plesiospitidiscus fasciger, JBH-

1371 B18, Crioceratites loryi Zone. C, Plesiospitidiscus fasciger, JBH-B20, Lyticoceras

1372 nodosoplicatum Zone. D, Plesiospitidiscus subdifficilis, JBH-B86, Subsaynella sayni-

1373 Plesiospitidiscus ligatus Zones. E, Plesiospitidiscus subdifficilis, JBH-B163, Balearites

1374 balearis Zone, Balearites binelli Subzone. F, Abrytusites neumaryi, JBH-B163, B. balearis

1375 Zone, B. binelli Subzone. G, Barremites gr. cassida, JBH-B234, T. hugii Zone. H,

1376 Valdedorsella? uhligi, JBH-B215, Pseudothurmannia ohmi Zone, Pseudothurmannia

1377 mortilleti Subzone. I, Discoidellia cf. couratieri, JBH-B86, S. sayni-P. ligatus Zones. J,

1378 Discoidellia cf. couratieri, JBH-B89, S. sayni-P. ligatus Zones.

1379

1380 Fig. 7. Ammonoids from the Jebel Boulahouajeb section (section JBH-B), Tunisia. Scale bar:

$13811 \mathrm{~cm}$; black arrow: end of phragmocone. A, Neolissoceras grasianum, JBH-B10,

1382 Acanthodiscus radiatus Zone. B, Phylloceras (Hypophylloceras) tethys, JBH-B10, A. radiatus 
Zone. C, Phyllopachyceras winkleri, JBH-B30, Lyticoceras nodosoplicatum Zone. D,

1384 Phyllopachyceras infundibulum, JBH-B9, A. radiatus Zone. E, Phyllopachyceras

1385 infundibulum, JBH-B86, Subsaynella sayni-Plesiospitidiscus ligatus Zones. F, Lytoceras

1386 subfimbriatum, JBH-B6, Criosarasinella furcillata Zone. G, Lytoceras subfimbriatum, JBH-

1387 B163, Balearites balearis Zone, Balearites binelli Subzone.

1388

1389

Fig. 8. Ammonoids from the Jebel Boulahouajeb section (section JBH-B), Tunisia. Scale bar:

$1 \mathrm{~cm}$; black arrow: end of phragmocone; SC: Silicone cast. A, Balearites cf. balearis, JBH-

B92, Balearites balearis Zone and Subzone. B, C, D, E, Balearites binelli, JBH-B163, B.

balearis Zone, B. binelli Subzone. F (SC), Balearites krenkeli?, JBH-B195, B. balearis Zone,

Balearites angulicostatus Subzone. G, H, Balearites cf. angulicostatus, JBH-B195, B.

balearis Zone, B. angulicostatus Subzone.

1395

Fig. 9. Ammonoids from the Jebel Boulahouajeb section (section JBH-B), Tunisia. Scale bar:

$1 \mathrm{~cm}$; black arrow: end of phragmocone; SC: Silicone cast. A, B, C, D, E, Pseudothurmannia mortilleti, JBH-B202, Pseudothurmannia ohmi Zone, P. mortilleti Subzone. F (SC), G (SC),

Pseudothurmannia pseudomalbosi, JBH-B202, P. ohmi Zone, P. mortilleti Subzone.

1401 Fig. 10. Ammonoids from the Jebel Boulahouajeb section (section JBH-B), Tunisia. Scale

1402 bar: $1 \mathrm{~cm}$; black arrow: end of phragmocone. A, Pseudothurmannia pseudomalbosi, JBH-

1403 B202, Pseudothurmannia ohmi Zone, Pseudothurmannia mortilleti Subzone. B,

1404 Pseudothurmannia picteti, JBH-B219, P. ohmi Zone, P. picteti Subzone. C, Paraspiticeras

1405 sp. ind., JBH-B161, Balearites balearis Zone and Subzone. D, Sabaudiella simplex, JBH-

1406 B215, P. ohmi Zone, P. mortilleti Subzone. 
1408 Fig. 11. Jebel Boulahouajeb section (section JBH-B), Tunisia, lithology and Hauterivian 1409 foraminifera distribution.

1410

1411 Fig. 12. Scanning Electronic Microscope (SEM) micrographs of selected foraminifera from 1412 the Jebel Boulahouajeb section (section JBH-B), Tunisia; the scale bar is indicated in

1413 brackets. A, Favusella hoterivica $(50 \mu \mathrm{m})$, JBH-B76. B, F. hoterivica $(50 \mu \mathrm{m})$, JBH-B109. C,

1414 Gorbachikella kugleri $(50 \mu \mathrm{m}), \mathrm{JBH}-\mathrm{B} 91 . \mathrm{D}$, G. kugleri $(10 \mu \mathrm{m}), \mathrm{JBH}-\mathrm{B} 231 . \mathbf{E}$,

1415 Gorbachikella anteroapertura $(10 \mu \mathrm{m}), \mathrm{JBH}-\mathrm{B} 172$. F, Praehedbergella sigali $(50 \mu \mathrm{m}), \mathrm{JBH}-$

1416 B221. G, P. sigali (50 $\mu \mathrm{m})$, JBH-B 225. H, P. sigali $(10 \mu \mathrm{m})$, JBH-B236. I, Lenticulina

1417 roemeri $(100 \mu \mathrm{m}), \mathrm{JBH}-\mathrm{B} 2$. J, Lenticulina eichenbergi $(100 \mu \mathrm{m})$, JBH-B44. K, Dorothia

1418 lilliformis $(100 \mu \mathrm{m})$, JBH-B31. L, Lenticulina multicella $(100 \mu \mathrm{m})$, JBH-B94. M, Dorothia

1419 praehauteriviana $(100 \mu \mathrm{m}), \mathrm{JBH}-\mathrm{B} 59 . \mathbf{N}$, Lenticulina ouachensis ouachensis $(100 \mu \mathrm{m}), \mathrm{JBH}-$

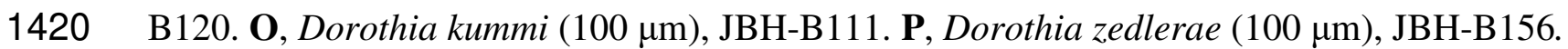

1421 Q, Lenticulina rotulata $(100 \mu \mathrm{m}), \mathrm{JBH}-\mathrm{B} 205 . \mathbf{R}$, Gavelinella barremiana $(50 \mu \mathrm{m}), \mathrm{JBH}-$

1422 B224.

1423

1424 Fig. 13. Correlations between the Jebel Bouahouajeb (JBH) and Jebel Oust (JO) sections for

1425 the uppermost Valanginian-lowermost Barremian interval. The Jebel Oust section (lithology,

1426 formations $4 \mathrm{~d}$ to 13 , ammonoid taxa and zonation) is after Memmi (1989). For abbreviations

1427 see Figure caption 3. 


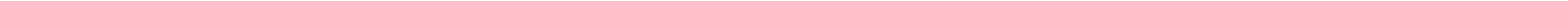




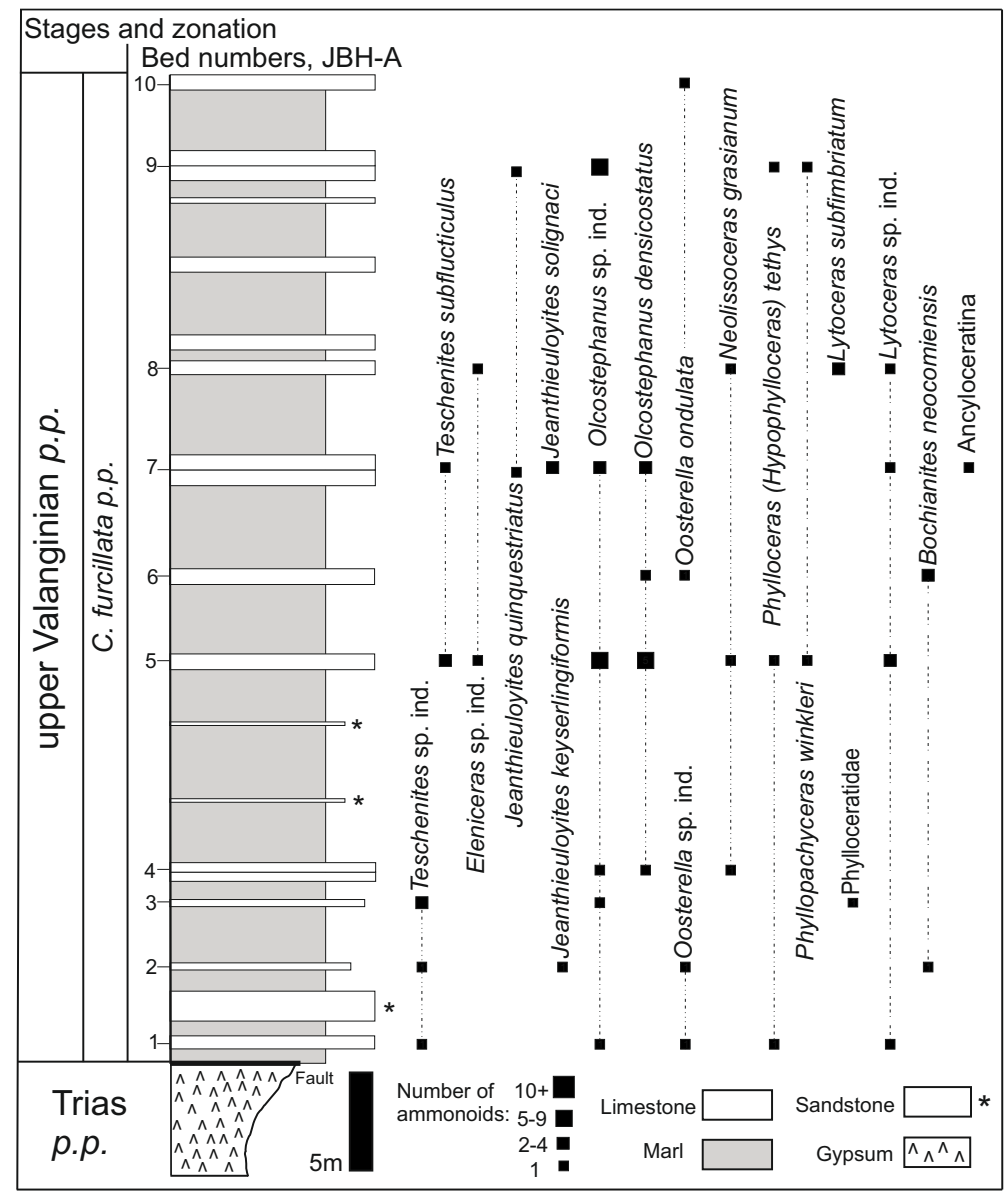




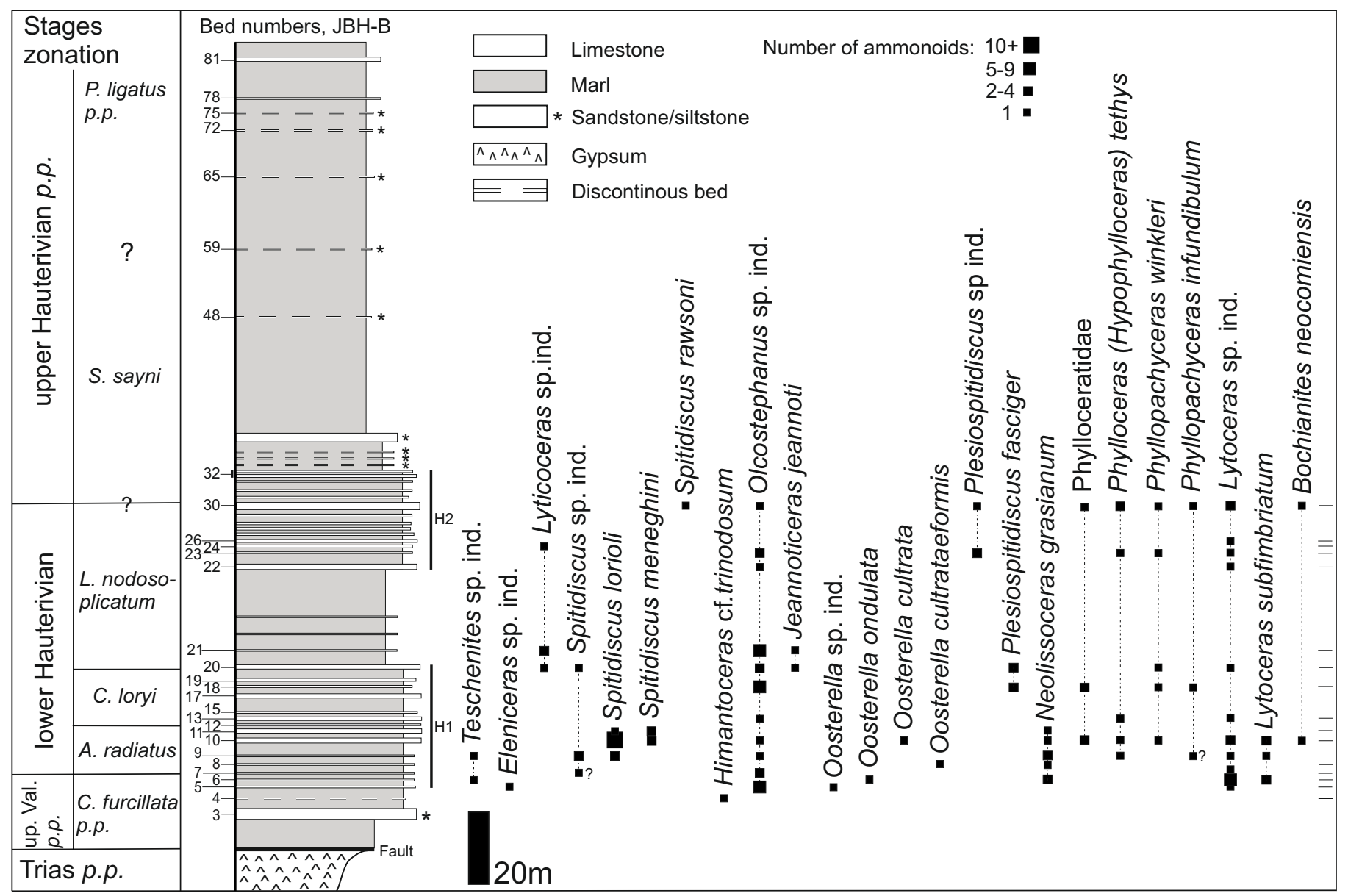




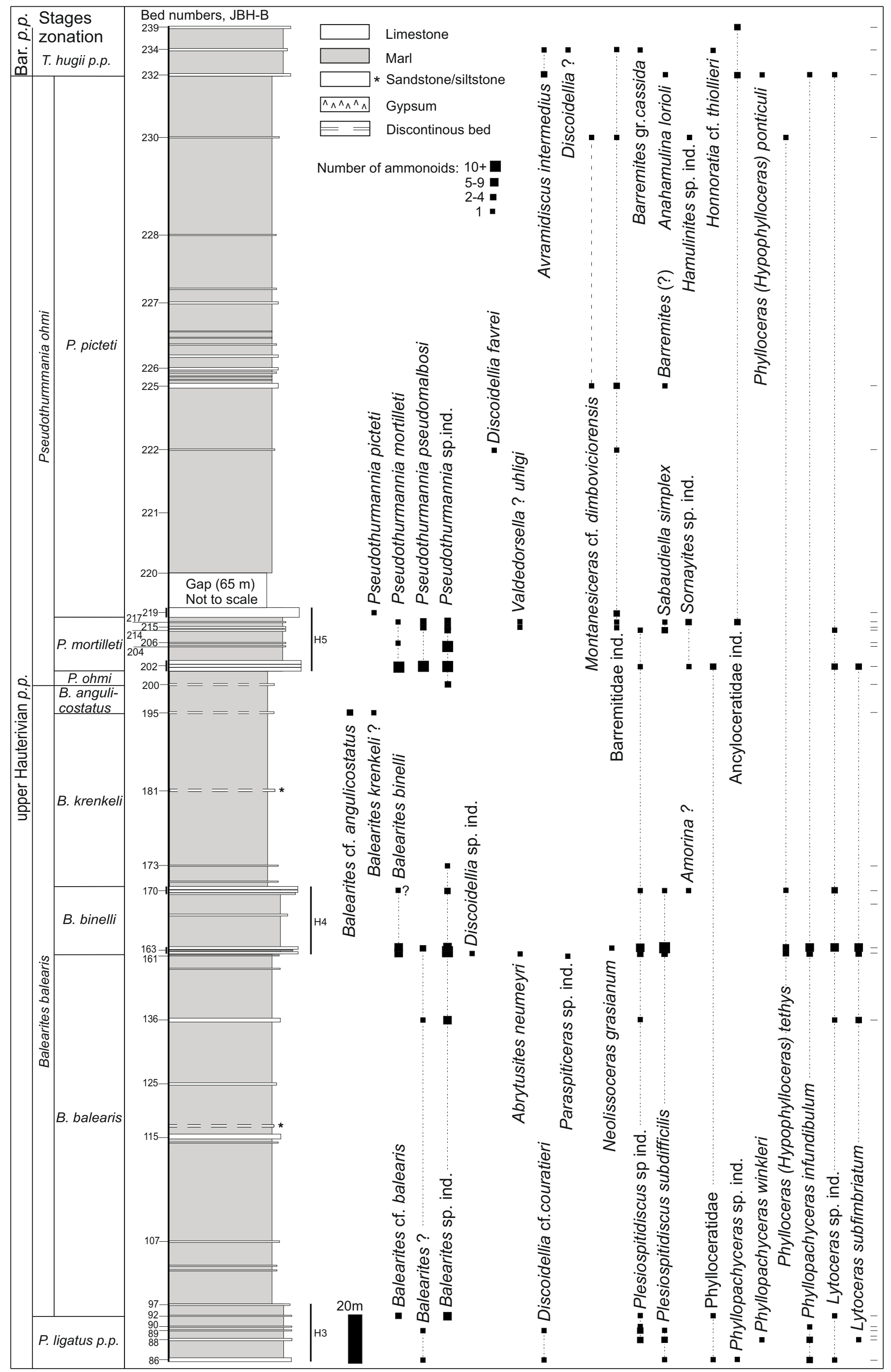



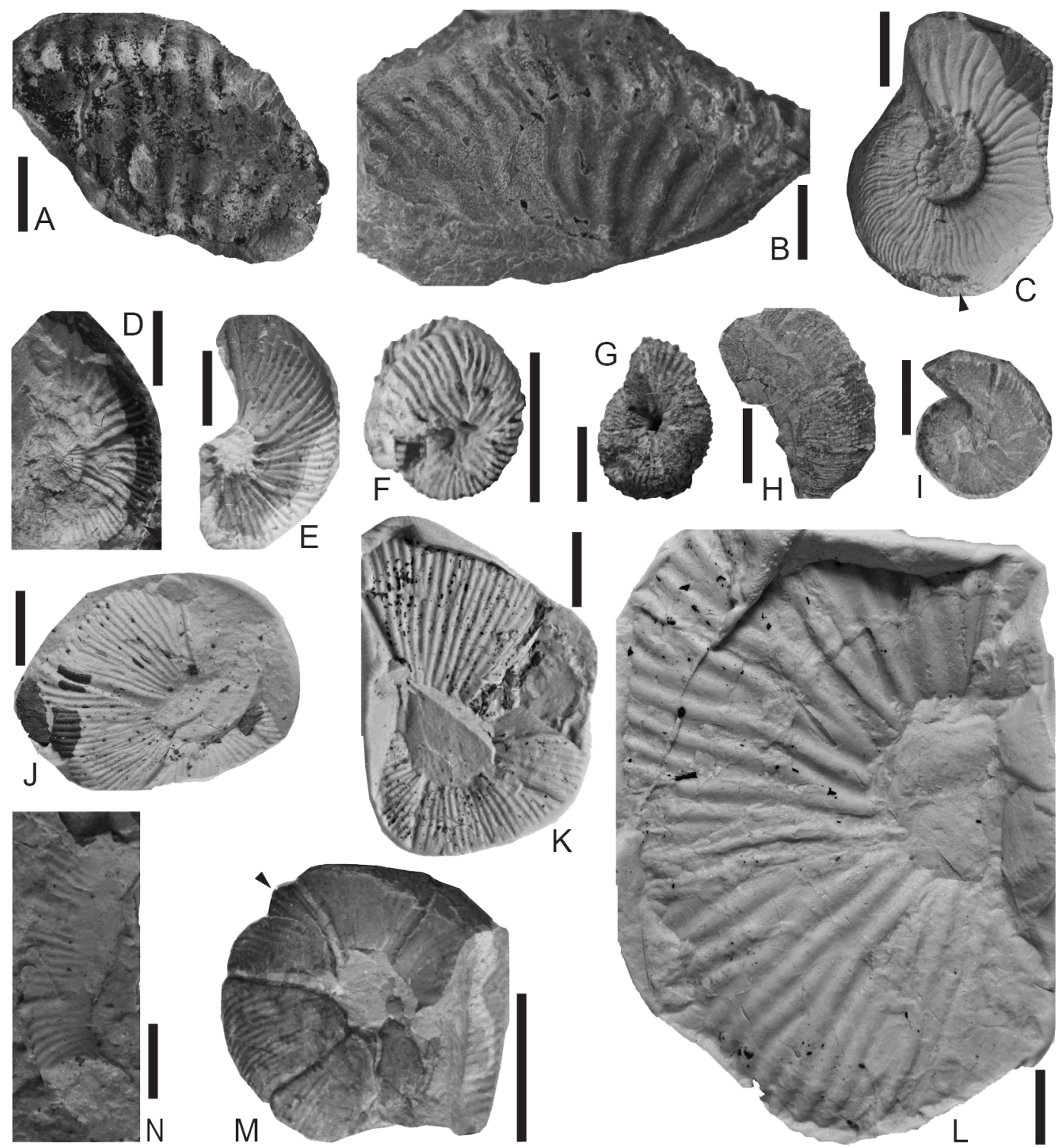


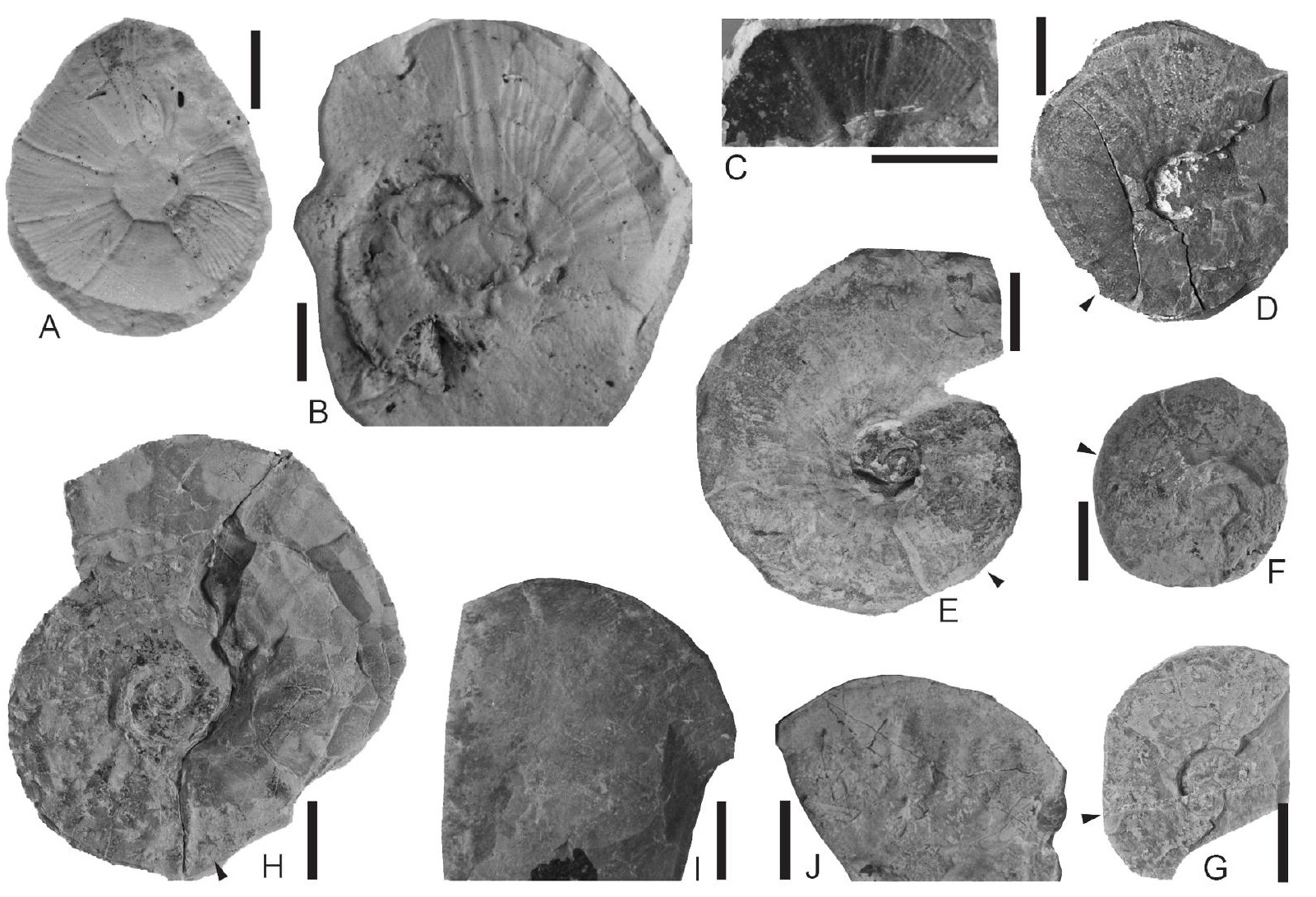




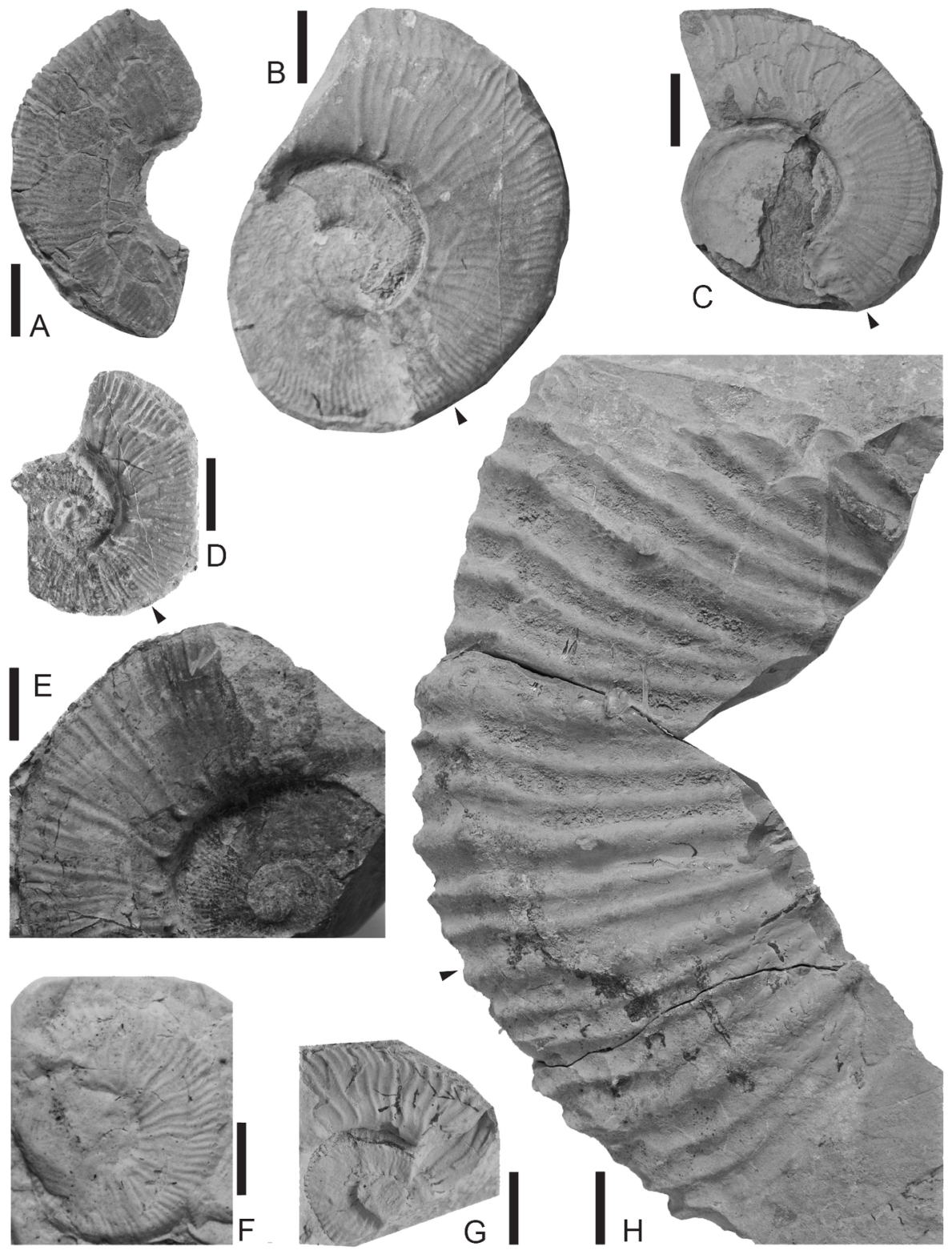




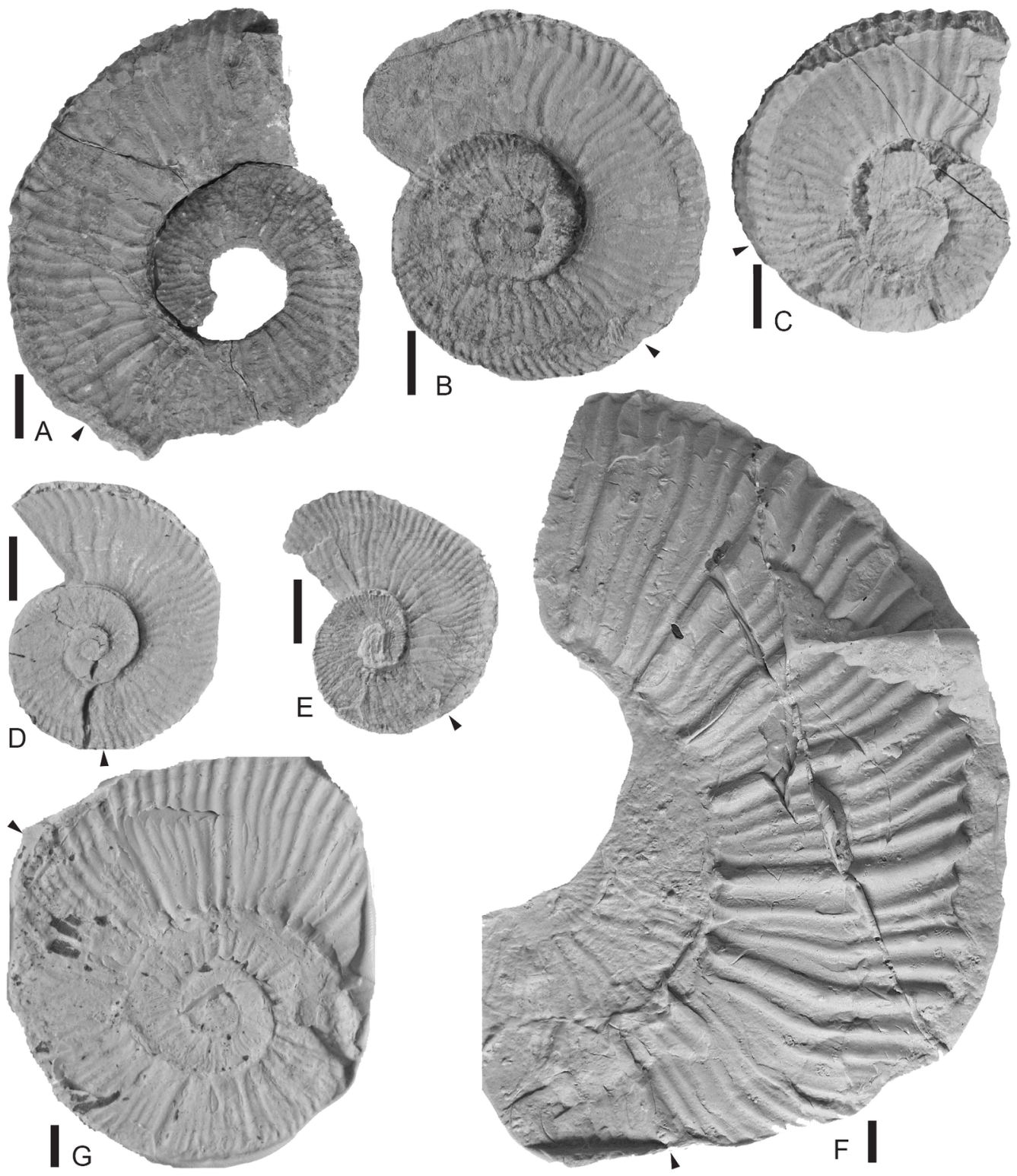




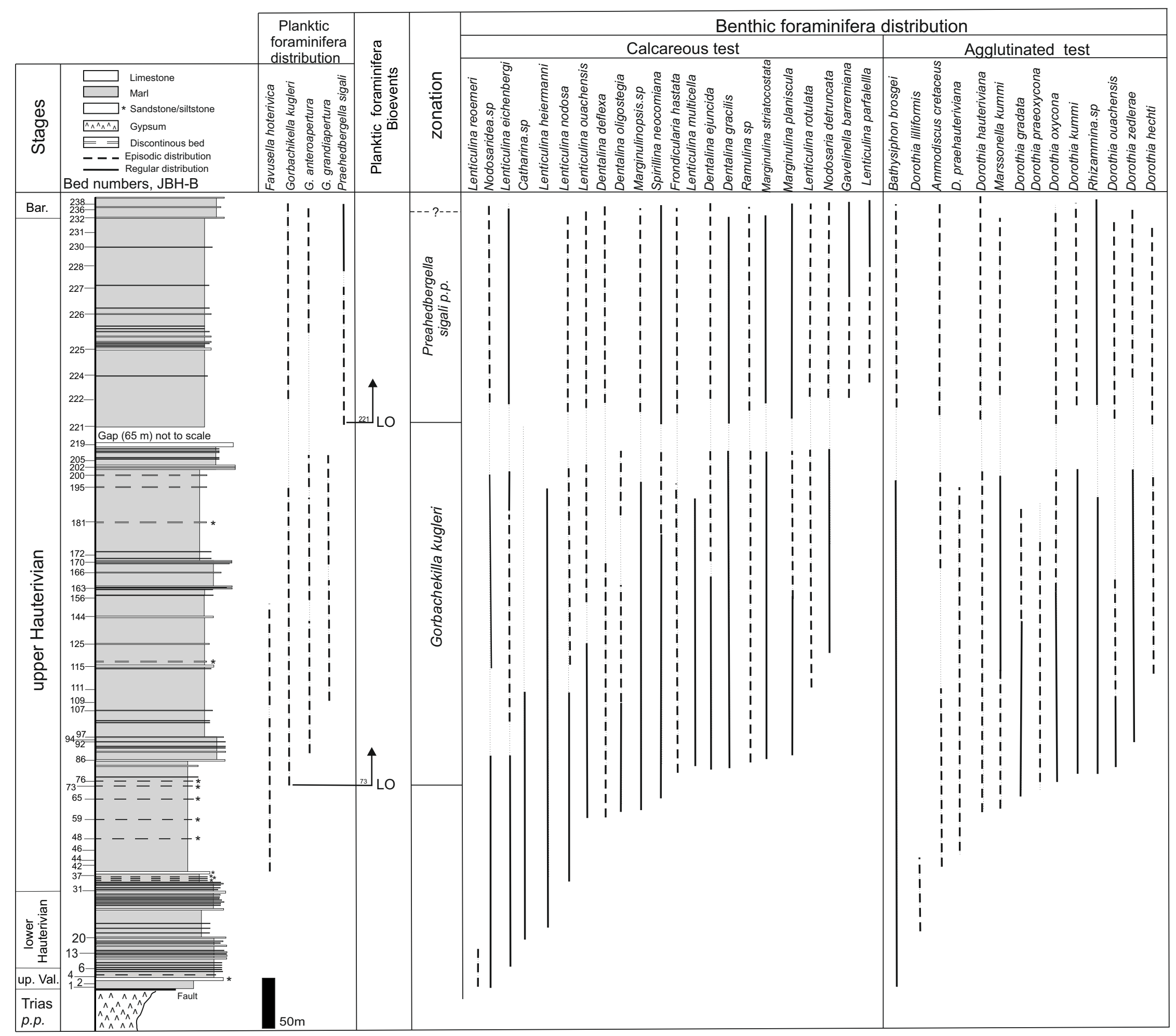



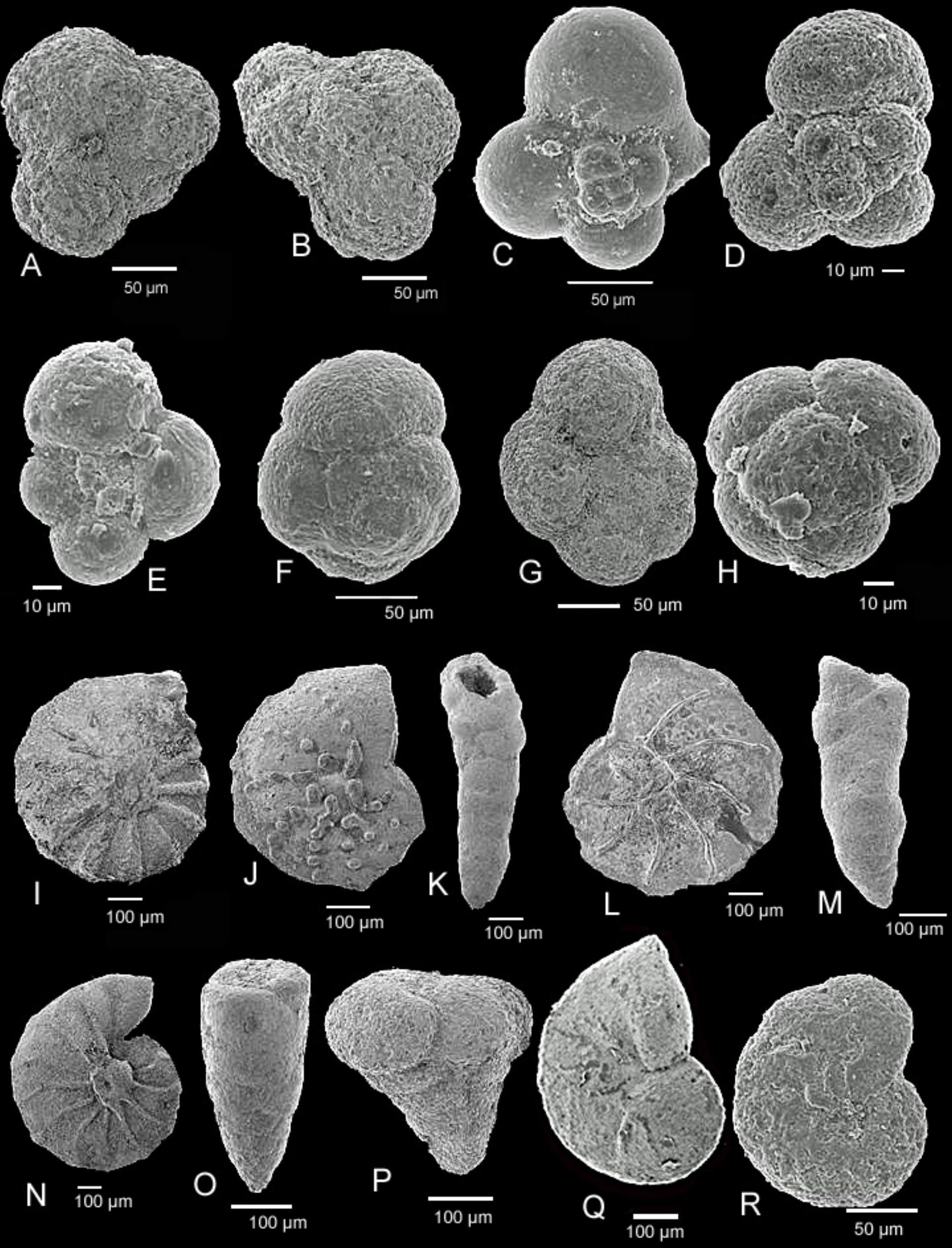
Jebel Boulahouajeb

Jebel Oust Formations - Zonation-Stages
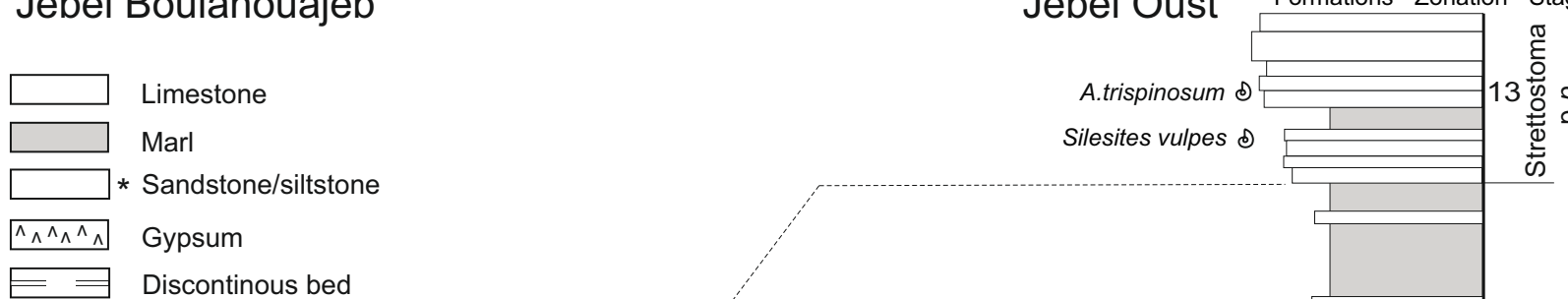
党

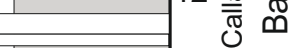

Valdedorsella sp. @

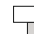

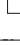

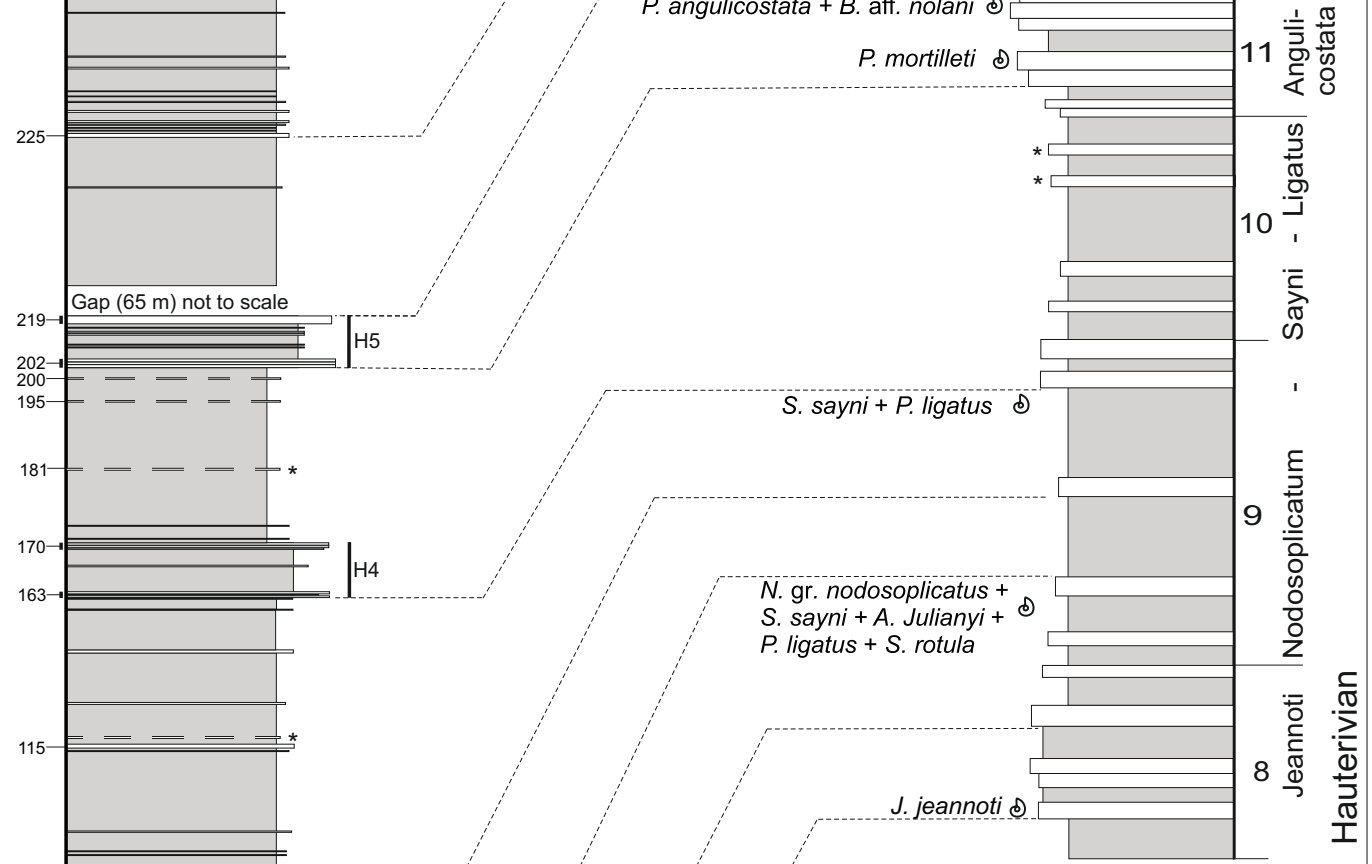

$1 \frac{1}{\frac{1}{5}} \frac{\pi}{\frac{\pi}{0}}$ 这

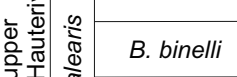

B. krenkeli
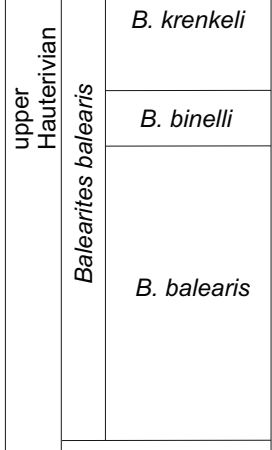

S. sayni
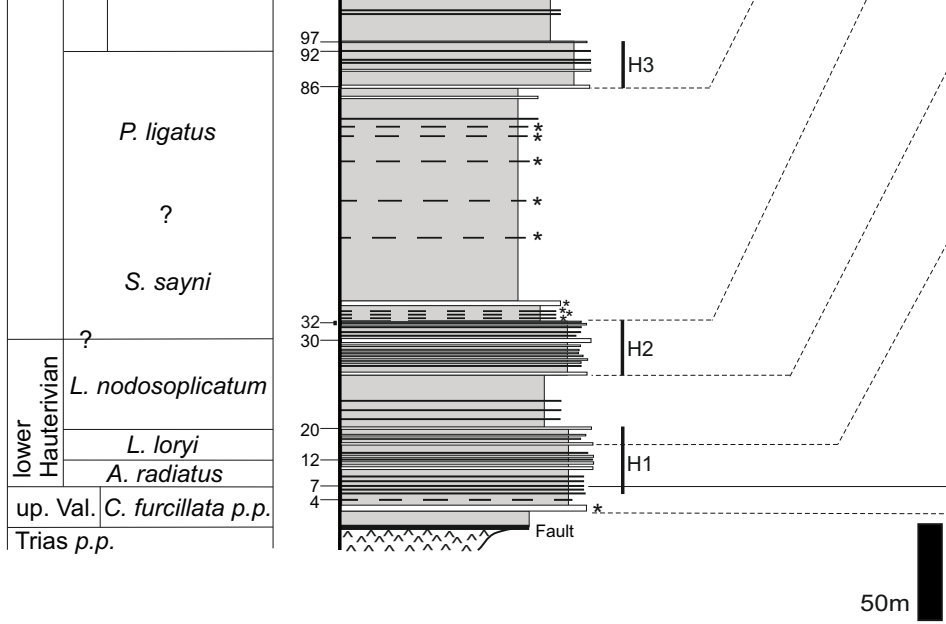

Gap (fault+river)

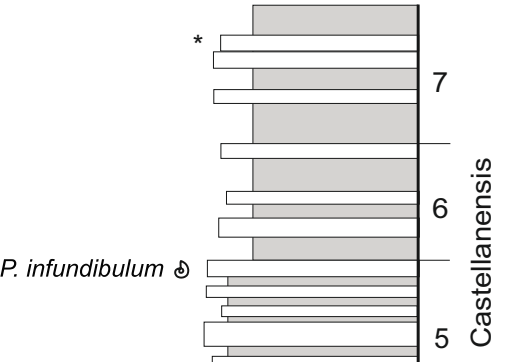

告

T. callisdiscus d

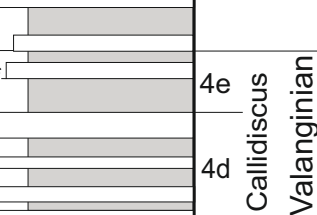

